\title{
Türkiye'de Muhasebe Standartları ile Finansal Raporlama Standartları Kapsamında Hazırlanan Lisansüstü Tezlerin Bibliyometrik Analizi*
}

\section{ÖZET}

Bu çalışmanın amacı küresel anlamda ortak bir muhasebe dilinin oluşturulmasında büyük önem taşıyan muhasebe standartları ile finansal raporlama standartları konusunda, ülkemizde yazılmış lisansüstü tezlerin bibliyometrik bir analizini sunmaktır. Bu kapsamda Yüksek Öğretim Kurumu (YÖK) Ulusal Tez Merkezi'nde sunulmuş 468 lisansüstü tez, belirli ölçütler bakımından incelenmiştir. Araştırma neticesinde, standartlar kapsamında ilk doktora tezinin 1992 yılında, en fazla lisansüstü tezin Marmara Üniversitesi'nde ve en fazla lisansüstü tezin sırastyla işletme, maliye, kamu yönetimi ve ekonomi anabilim dallarında yazıldığı ortaya konulmuştur. Ayrıca tezlerde en çok kullanılan araştırma yöntemi BiST uygulamasıdır. Doktora tezleri en fazla standartlar ile vergi mevzuatı kapsamındaki değerleme ölçütlerinin karşılaştırllması, Avrupa'daki standartlarının Türkiye muhasebe standartları ile karşılaştırılması konularında, yüksek lisans tezleri ise stoklar standardı konusunda yazılmıştır. Çalışmada lisansüstü tezlere konu olmamış bir muhasebe standardı ve iki finansal raporlama standardı saptanmıştır. Bunlar TFRS 6- Maden Kaynaklarının Araştırılması ve Değerlendirilmesi, TFRS 14- Düzenlemeye Dayalı Erteleme Hesapları, TMS 26- Emeklilik Fayda Planlarında Muhasebeleştirme ve Raporlama standartlarıdır.

Anahtar Kelimeler: Muhasebe Standartları, Finansal Raporlama Standartları, Bibliyometri, İçerik Analizi, Lisansüstü Tezler.

JEL Siniflandırması: M40, M49.

\section{Bibliometric Analysis of Graduate Thesis Prepared in the Scope of Accounting} Standards and Financial Reporting Standards in Turkey

\section{ABSTRACT}

The aim of this study is to present a bibliometric analysis of the postgraduate work written in our country on accounting and financial reporting standards, which are of great importance for the creation of a global common language of financial reporting. In this context, 468 post-graduate theses submitted to the University Council (YOeK National Thesis Center) were analyzed with regard to specific criteria. As a result of the investigation, it was found that the first doctoral thesis was written in 1992 and most of the theses were written in Marmara University the fields of business administration, finance, public administration and economics. Furthermore, the most frequently used research method for doctoral theses is BIST application. Comparison of the doctoral thesis with most standard assessment criteria according to tax laws, accounting standards, standards compared with Turkey European topics written in standard stocks of the master thesis. The study identified one accounting standard and two accounting standards that were not the subject of the doctoral thesis. These are TFRS 6 Research and Evaluation of Mineral Resources, TFRS 14 Regulatory Deferral Accounts, TMS 26 Recognition and Reporting in Retirement Benefit Plans. Theses.

Keywords: Accounting Standards, Financial Reporting Standards, Bibliometry, Content Analysis, Postgraduate Jel Classification: M40, M49.

\footnotetext{
* Makale Gönderim Tarihi: 19.02.2021, Makale Kabul Tarihi: 09.07.2021, Makale Türü: Nitel Araştırma

** Dr, Uşak Üniversitesi, feden.koc@usak.edu.tr, ORCID: 0000-0003-4413-5188
} 


\section{GİRİş}

Küresel yelpazede ortak bir muhasebe dilinin oluşturulması ihtiyacının bir sonucu olarak, Avrupa Birliği (AB) tarafından 2002 yılında onaylanmış Uluslararası Muhasebe Standartları (UMS) ve paralelinde Uluslararası Finansal Raporlama Standartları (UFRS)'na ilişkin düzenlemeler ülkemizde mevcut muhasebe uygulamalarını da etkilemiştir. Ülkemizde 1994 yılında Türkiye Muhasebe ve Denetim Standartları Kurulu (TMUDESK) ile 1999 yılında Türkiye Muhasebe Standartları Kurulu (TMSK)'nun kurulması uluslararası muhasebe standartları ile uyumlaştırma surecini başlamıştır (Akdoğan, 2006: 2-3). Bu uyumlaştırma sürecinde Uluslararası Muhasebe Standartları Kurulu (International Accounting Standards Board-IASB) ile imzalanan telif anlaşması kapsamında, Uluslararası Muhasebe Standartları (International Accounting Standards -IAS) ve Uluslararas1 Finansal Raporlama Standartları (International Financial Reporting Standards -IFRS) Türkçeye, Türkiye Muhasebe Standartları/Türkiye Finansal Raporlama Standartları (TMS/TFRS) olarak çevrilmiş ve ülkemizde halka acık faaliyet gösteren şirketlerin muhasebe uygulamalarında esas almaları üzere Resmi Gazete'de yayımlanarak yürürlüğe girmiştir

TMS/TFRS'nin ülkemiz muhasebe sisteminde esas alınması ile birlikte, mevcut muhasebe uygulamaları değerleme, hesaplama, raporlama gibi daha birçok konuda etkilenmiştir (Koç, 2018: 2). Bu çalışma kapsamında da ülkemizde muhasebe standartları ve finansal raporlama standartları konusunda hazırlanmış lisansüstü tezlerin bibliyometrik bir analizi sunularak, ülkemizde bu standartlara ilişsin hazırlanan lisansüstü tezlerin gelişimi ve geleceğe ilişkin eğilimi belirlenmeye çalışılmıştır. Bu kapsamda çalışma, lisansüstü tezler ile sınırlı tutulmuştur. Muhasebe ve finansman alanında bibliyometrik analiz yönteminin araştırma yöntemi olarak kullanıldı̆̆ı, literatürdeki bazı çalışmalara ilişkin özet bir gösterim Tablo 1'de sunulmuştur.

Tablo 1. Muhasebe ve Finansman Alanında Bibliyometrik Analiz Yönteminin Araştırma Yöntemi Olarak Kullanıldığı Literatürdeki Çalışmalara İlişskin Bilgiler

\begin{tabular}{|c|c|c|c|c|}
\hline Yazarlar & Çalışmanın Amacı & $\begin{array}{l}\text { Çalışmadan } \\
\text { Sonuçlar }\end{array}$ & $\begin{array}{l}\text { Çalışmanın } \\
\text { Türü }\end{array}$ & $\begin{array}{l}\text { Çalışmanın } \\
\text { Künyesi }\end{array}$ \\
\hline $\begin{array}{l}\text { Fallatah, } \\
\text { Emad \& } \\
\text { Mohd Saat, } \\
\text { Nur } \\
\text { Ashikin \& } \\
\text { Shah, } \\
\text { Sabarina } \\
\text { Mohamme } \\
\text { d \& Choo, } \\
\text { Wei Chong }\end{array}$ & $\begin{array}{l}\text { Çalışma muhasebe ve } \\
\text { denetim alanında } \\
\text { akademik ve profesyonel } \\
\text { literatüre nicel bir genel } \\
\text { bakış } \\
\text { UFRS'nin benimsengarak } \\
\text { ve denetimin kalitesine } \\
\text { etkisine ilişkin literatürün } \\
\text { araştırılmasını } \\
\text { amaçlamaktadır. }\end{array}$ & $\begin{array}{lr}\text { Çalışma kapsamında } & \text { 2005-2019 } \\
\text { y1lları arasında IFRS ve denetimin } \\
\text { kalitesine etkisine } r \text { ilişkin, } \\
\text { araştırma alanında } 1019 \text { belgeyi } \\
\text { içeren Scopus veritabanına dayalı } \\
\text { olarak Vosviewer ve } & \text { Microsoft } \\
\text { excel araçları } & \text { kullanılarak } \\
\text { bibliyometrik } & \text { analiz } \\
\text { gerçekleştirilmiştir. Çalışmanın } \\
\text { sonucunda, Avrupa } \\
\text { ülkeleri ve gelişmekte olan } \\
\text { piyasaların çoğunluğ tarafından } \\
\text { IFRS'nin benimsenmesi önemi ve } \\
\text { 2008 mali krizinin ardından } \\
\text { denetim kalitesinin } \\
\text { vurgulanmıştır. }\end{array}$ & $\begin{array}{l}\text { Uluslararası } \\
\text { makale }\end{array}$ & $\begin{array}{l}\text { (Fallatah, } \\
\text { Saat, Shah } \\
\text { ve Chong, } \\
\text { 2021: 1-14) }\end{array}$ \\
\hline $\begin{array}{l}\text { Ezenwoke, } \\
\text { Omotola \& } \\
\text { Tion, } \\
\text { Williams \& } \\
\text { Oku, }\end{array}$ & $\begin{array}{lr}\text { Çalışma } & \text { kapsamında } \\
\text { Afrika'da } & \text { uluslararası } \\
\text { finansal } & \text { raporlama } \\
\text { standartlarının } & \\
\text { benimsenmesine } & \text { ilişkin } \\
\end{array}$ & $\begin{array}{l}\text { Çalışmadan elde edilen sonuçlar, } \\
\text { Zimbabve'de uluslararası finansal } \\
\text { raporlama standartlarının } 1993 \\
\text { yılında benimsenmesine rağmen, } \\
\text { Afrika'da IFRS'ye ilişkin Scopus }\end{array}$ & $\begin{array}{l}\text { Uluslararası } \\
\text { makale }\end{array}$ & $\begin{array}{l}\text { (Ezenwoke } \\
\text { ve Tion, } \\
\text { 2020: } 1-20)\end{array}$ \\
\hline
\end{tabular}




\begin{tabular}{|c|c|c|c|c|}
\hline Robert & $\begin{array}{l}\text { bibliyometrik bir analiz } \\
\text { sunulmuştur. Analiz, } \\
\text { 2005-2018 yılları arasında } \\
\text { Scopus veritabanında } \\
\text { listelenmiş olan } 73 \\
\text { makaleyi kapsamaktadır. }\end{array}$ & 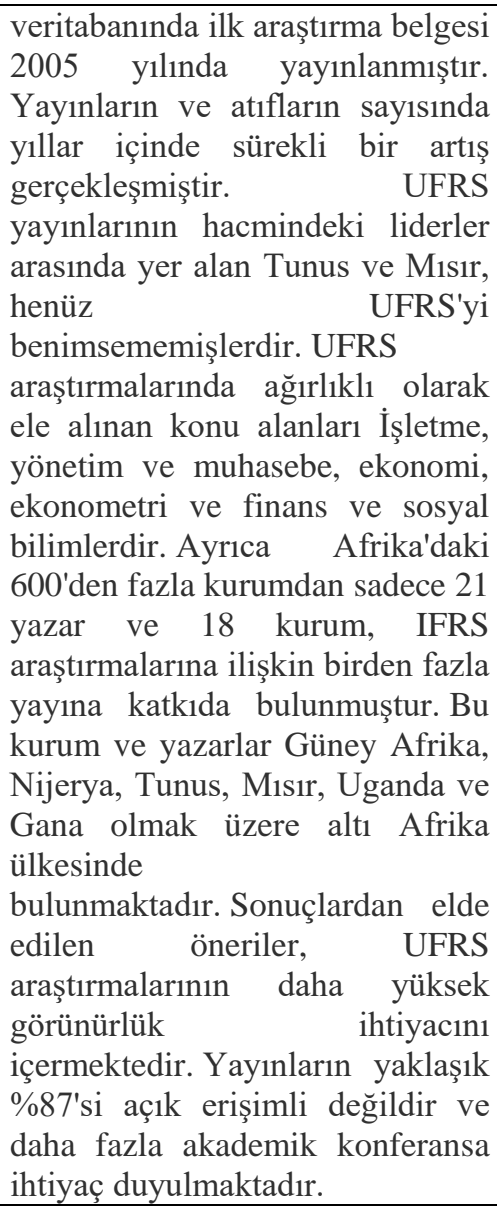 & & \\
\hline $\begin{array}{l}\text { Balstad, } \\
\text { Marit } \\
\text { Terese \& } \\
\text { Berg, Terje }\end{array}$ & 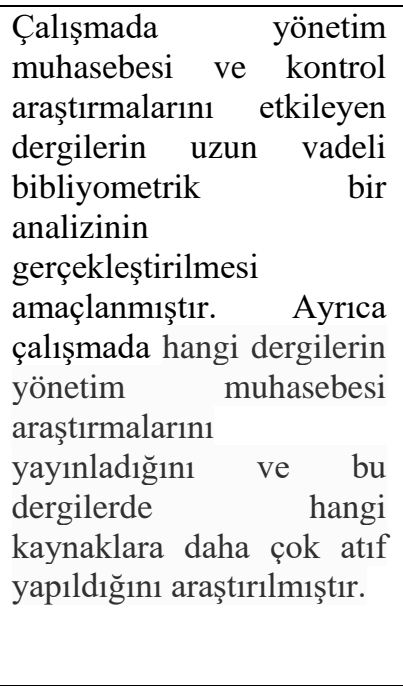 & $\begin{array}{l}\text { Çalışma kapsamında web of } \\
\text { Science ve Scopus'tan alınan } \\
\text { alıntı verilerine göre, 1945-2018 } \\
\text { ve 1960-2018 zaman dilimlerinde } \\
\text { ilgili her bir veri tabanından } \\
506.753 \text { ve } 1.075 .838 \text { alıntı } \\
\text { yapılan referans analiz edilerek, } \\
\text { yönetim muhasebesinin sınırları } \\
\text { incelenmiş ve en çok alıntı } \\
\text { yapılan beş derginin toplam } \\
\text { alıntıların \%6,5'ini ve \%4,7'sini } \\
\text { temsil ettiği sonucuna } \\
\text { ulaşılmıştır. Hem Web of Science } \\
\text { hem de Scopus'ta en çok atıf alan } \\
\text { dergiler sirasıla AOS ve } \\
\text { ardından MAR olarak tespit } \\
\text { edilmiştir. }\end{array}$ & $\begin{array}{l}\text { Uluslararası } \\
\text { makale }\end{array}$ & $\begin{array}{l}\text { (Balstad ve } \\
\text { Berg, 2020: } \\
\text { 357-380) }\end{array}$ \\
\hline $\begin{array}{l}\text { Durgut, } \\
\text { Sinan }\end{array}$ & $\begin{array}{lr}\text { Türkiye'de } & \text { yazılan } \\
\text { akademik } & \text { makalelerin } \\
\text { mevcut } & \text { durumunun } \\
\text { bibliyometrik } & \text { analiz } \\
\text { yöntemi ile } & \text { incelenmesi } \\
\text { amaçlanmıştır. } & \text { Bu } \\
\text { kapsamda Web of Science } \\
\text { atıf veri } \quad \text { tabanından }\end{array}$ & $\begin{array}{l}\text { Alan bazında incelendiğinde en } \\
\text { çok yayın yapan üniversiteler, } \\
\text { üniversite bazında en çok yayın } \\
\text { yapan yazarlar, birlikte çalışma } \\
\text { yapmış ve yapma ihtimali olan } \\
\text { üniversiteler ile birlikte çalışma } \\
\text { yapmışlar ve birlikte çalışma } \\
\text { yapma ihtimali olan yazarlar }\end{array}$ & $\begin{array}{l}\text { Yüksek } \\
\text { lisans tezi }\end{array}$ & $\begin{array}{l}\text { (Durgut, } \\
\text { 2020: 83) }\end{array}$ \\
\hline
\end{tabular}




\begin{tabular}{|c|c|c|c|c|}
\hline & $\begin{array}{l}\text { Türkiye adresli olan ve } \\
\text { 1980-2019 yılları arasında } \\
\text { yazılmış olan toplam } \\
585.236 \text { adet makale } \\
\text { amaçlar doğrultusunda } \\
\text { filtrelenip, 220.969 adet } \\
\text { akademik makale analiz } \\
\text { edilmiştir. }\end{array}$ & $\begin{array}{l}\text { belirlenerek sunulmuştur. Bu } \\
\text { kapsamda en çok makale } \\
\text { yayınlayan ve en çok atıf alan } \\
\text { üniversiteler arasında İstanbul } \\
\text { Üniversitesi, } \\
\text { Üniversitesi, Gazi Üniversitesi, } \\
\text { Ege Üniversitesi ve Ankara } \\
\text { Üniversitesi yer almaktadır. } \\
\text { Ayrıca 2008- 2015 yılları arasında } \\
\text { akademik makale sayıları önemli } \\
\text { ölçüde artmıştır. Ülkemizde en } \\
\text { fazla yayının bilim ve teknoloji } \\
\text { alanında yapıldı̆̆1, en az yayının } \\
\text { ise beşerî bilimler alanında } \\
\text { yapıldığı tespit edilmiştir. } \\
\text { Birliktelik analizi sonuçlarına } \\
\text { göre en çok birlikte çalışma yapan } \\
\text { ilk } 3 \text { üniversite } 783 \text { akademik } \\
\text { çalışma ile Gazi ve Hacettepe } \\
\text { üniversiteleri, } 763 \text { akademik } \\
\text { çalışma ile Gazi ve Ankara } \\
\text { üniversiteleri, } 676 \text { çalışma ile } \\
\text { Ankara ve Hacettepe } \\
\text { üniversiteleri olmuştur. Beraber } \\
\text { çalışma yapan üniversiteler } \\
\text { incelendiğinde, beraber çalışma } \\
\text { yapmayı etkileyen en önemli } \\
\text { faktörün bulundukları konum } \\
\text { olduğu görülmüştür. En çok } \\
\text { birlikte akademik çalışma yapan } \\
\text { yazarlar ise 95 akademik çalışma } \\
\text { ile B. Cakir ve R. Ersoy, } 78 \\
\text { çalışma ile M. Soylak ve M. } \\
\text { Tuzen, 77 akademik çalışma ile } \\
\text { Y. Atalay ve D. Avci'dır. }\end{array}$ & & \\
\hline $\begin{array}{l}\text { Dworczak, } \\
\text { Beata } \\
\text { Zyznarska } \\
\& \quad \text { Sačer, } \\
\text { Ivana } \\
\text { Mamić }\end{array}$ & $\begin{array}{lr}\text { Çalışmada } & \text { Hırvatistan } \\
\text { Cumhuriyeti } & \text { ve } \\
\text { Polonya'daki } & \text { muhasebe } \\
\text { sistemlerinin } & \text { temel } \\
\text { farklılıklarının } & \\
\text { araştırılması } & \\
\text { amaçlanmaktadır. } & \text { Bu } \\
\text { kapsamda bibliyometrik } \\
\text { analiz yöntemi ile Polonya } \\
\text { ve Hırvat } & \text { muhasebe } \\
\text { standartları ile yasal } \\
\text { düzenlemeler } & \text { tarafından } \\
\text { yapılan } & \text { bilimsel } \\
\text { literatürün eleştirel bir } \\
\text { analizi gerçekleştirilmiştir. }\end{array}$ & $\begin{array}{l}\text { Endüktif ve tümdengelimli } \\
\text { muhakemeye dayanan makale, } \\
\text { Hırvatistan ve Polonya'daki } \\
\text { muhasebe çerçevelerinin temel } \\
\text { belirleyicilerini ve farklılıklarını } \\
\text { ortaya koymaktadır. Ayrıca } \\
\text { çalışma karşılaştırmalı } \\
\text { uluslararası muhasebe } \\
\text { araştırmalarında ekonomik ve } \\
\text { kültürel farklılıkları dikkate } \\
\text { almanın oldukça önemli olduğunu } \\
\text { kanıtlamaktadır. }\end{array}$ & $\begin{array}{l}\text { Uluslararası } \\
\text { makale }\end{array}$ & $\begin{array}{l}\text { (Dworczak } \\
\text { ve Sačer } \\
\text { 2019: } 55-72)\end{array}$ \\
\hline
\end{tabular}




\begin{tabular}{|c|c|c|c|c|}
\hline $\begin{array}{l}\text { Çarıkçı, } \\
\text { Oğuzhan \& } \\
\text { Yaman, } \\
\text { Bahar }\end{array}$ & $\begin{array}{l}\begin{array}{l}\text { Türkiye'de } \\
\text { akademik dergilerde, } \\
\text { muhasebe veya finans }\end{array} \\
\text { öğrencilerini kapsayan } \\
\text { makalelerin incelenmesi } \\
\text { amaçlanmıştır. }\end{array}$ & $\begin{array}{l}\text { Muhasebe veya finansman } \\
\text { alanında bulunan } 2.564 \text { yayın } \\
\text { arasından } 54 \text { tanesi muhasebe } \\
\text { veya finans öğrencilerine yönelik } \\
\text { olarak hazırlanmıştır. }\end{array}$ & $\begin{array}{l}\text { Ulusal } \\
\text { makale }\end{array}$ & $\begin{array}{l}\text { (Çarıkçı ve } \\
\text { Yaman, } \\
\text { 2019: } \\
\text { 381) }\end{array}$ \\
\hline $\begin{array}{l}\text { Özbek, } \\
\text { Cevdet } \\
\text { Yiğit \& } \\
\text { Badem, } \\
\text { Ahmet } \\
\text { Cemkut }\end{array}$ & $\begin{array}{lr}\text { Muhasebe } & \text { ve } \\
\text { Uygulamaları } & \text { Dergisi’nde } \\
\text { yayımlanan } & \text { makalelerin } \\
\text { bibliyometrik } & \text { bir } \\
\text { analizinin } & \text { yapılması } \\
\text { amaçlanmıştır. } & \end{array}$ & 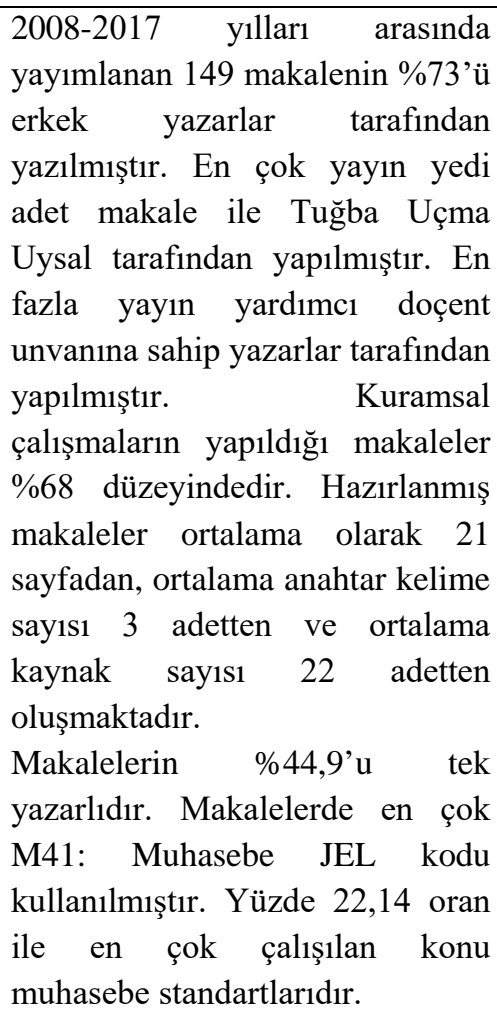 & $\begin{array}{l}\text { Ulusal } \\
\text { makale }\end{array}$ & $\begin{array}{l}\text { (Özbek ve } \\
\text { Badem, } \\
\text { 2018: 216- } \\
\text { 247) }\end{array}$ \\
\hline $\begin{array}{l}\text { Yeşil, } \\
\text { Tolga } \quad \& \\
\text { Akyüz, } \\
\text { Fatma }\end{array}$ & $\begin{array}{l}\text { Türkiye'de muhasebe } \\
\text { alanında yazılmış doktora } \\
\text { tezlerinin bibliyometrik } \\
\text { bir analizi yapılmaya } \\
\text { çalışılmıştır. }\end{array}$ & 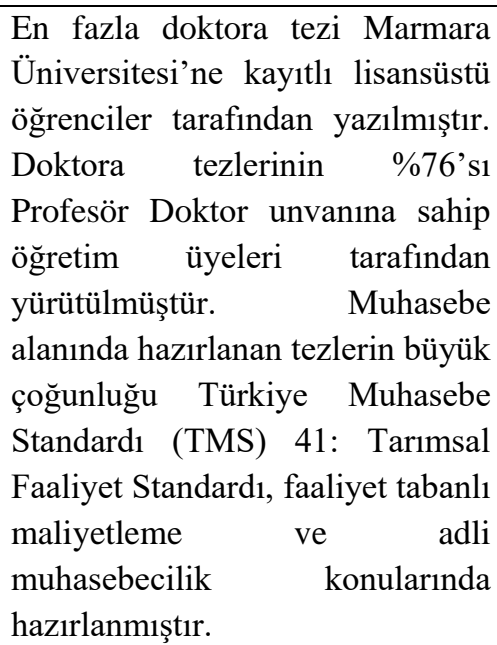 & $\begin{array}{l}\text { Ulusal } \\
\text { makale }\end{array}$ & $\begin{array}{l}\text { (Yeşil ve } \\
\text { Akyüz, } \\
\text { 2018: } \\
\text { 472) }\end{array}$ \\
\hline $\begin{array}{l}\text { Gündüz, } \\
\text { Meral }\end{array}$ & $\begin{array}{lr}2014-2016 & \text { yıllarında } \\
\text { akademik } & \text { dergilerde, } \\
\text { muhasebe } & \text { alanında } \\
\text { yayımlanmıs } & \text { bulunan } \\
\text { makalelerin } & \text { bibliyometrik }\end{array}$ & 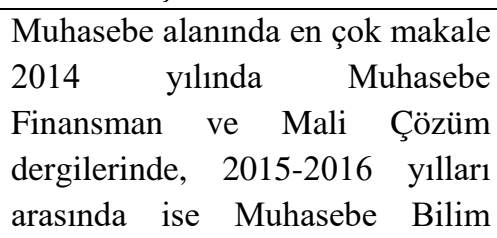 & $\begin{array}{l}\text { Ulusal } \\
\text { makale }\end{array}$ & $\begin{array}{l}\text { (Gündüz, } \\
\text { 2018: 236- } \\
\text { 257) }\end{array}$ \\
\hline
\end{tabular}




\begin{tabular}{|c|c|c|c|c|}
\hline & $\begin{array}{l}\text { bir analizinin sunulması } \\
\text { amaçlanmıştır. }\end{array}$ & 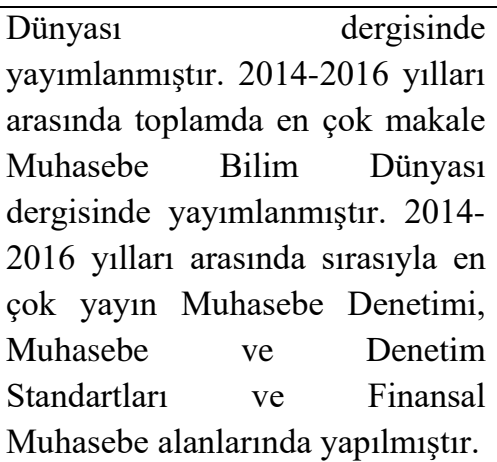 & & \\
\hline $\begin{array}{l}\text { Merig'o, } \\
\text { Jos'e M. \& } \\
\text { Yang, Jian- } \\
\text { Bo }\end{array}$ & $\begin{array}{l}\text { Çalışma kapsamında web } \\
\text { of science veri tabanını } \\
\text { kullanan muhasebe } \\
\text { araştırmaları ile ilgili } \\
\text { bibliyometrik bir analizin } \\
\text { gerçekleştirilmesi } \\
\text { amaçlanmıştır. }\end{array}$ & $\begin{array}{l}\text { Çalışmadan elde edilen sonuçlar, } \\
\text { muhasebe araştırmaları alanında } \\
\text { en etkili dergilerin The Journal of } \\
\text { Accounting and Economics, } \\
\text { Journal of Accounting Research, } \\
\text { The Accounting Reiew and } \\
\text { Accounting, Organizations and } \\
\text { Society olduğunu göstermektedir. } \\
\text { Ayrıca ABD kurumlarının dünya } \\
\text { çapında en etkili kurumlar olduğu } \\
\text { tespit edilmiştir. }\end{array}$ & $\begin{array}{l}\text { Uluslararası } \\
\text { makale }\end{array}$ & $\begin{array}{l}\text { (Merigó and } \\
\text { Yang, 2017: } \\
\text { 71-100) }\end{array}$ \\
\hline $\begin{array}{l}\text { Zhong, } \\
\text { Shaozhuo } \\
\& \quad \text { Geng, } \\
\text { Yong \& } \\
\text { Liu, } \\
\text { Wenjing \& } \\
\text { Gao, } \\
\text { Cuixia \& } \\
\text { Chen, Wei }\end{array}$ & 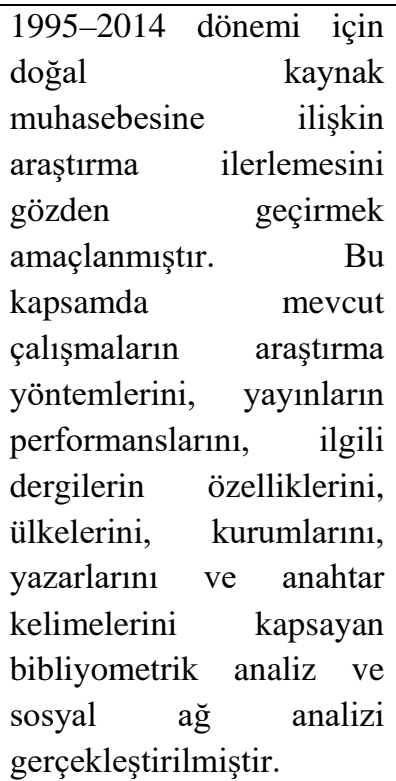 & $\begin{array}{l}\text { Doğal kaynak muhasebesi ile } \\
\text { ilgili toplam yayın sayısının } \\
2001 \text { 'den bu yana hızla arttığı } \\
\text { sonucuna ulaşılmıştır. Bu alanda } \\
\text { en verimli dergi, ülke, kurum ve } \\
\text { yazar sırasıyla ABD, Kaliforniya } \\
\text { Üniversitesi ve Kaliforniya } \\
\text { Üniversitesi Çevre Yönetimi } \\
\text { Dergisi ile Dr. Chen'dir. En çok } \\
\text { ilgi çeken doğal kaynaklar ise su } \\
\text { ve enerji . Bu alandaki altı ana } \\
\text { araştırma yöntemi ise matematik } \\
\text { modelleme, emerji, } \\
\text { ekserji, ekolojik ayak izi (EF), } \\
\text { yaşam döngüsü değerlendirmesi } \\
\text { (LCA) ve malzeme } \\
\text { alizini (MFA)’dir. }\end{array}$ & $\begin{array}{l}\text { Uluslararası } \\
\text { makale }\end{array}$ & $\begin{array}{l}\text { (Zhong, } \\
\text { Geng, Liu, } \\
\text { Gao ve } \\
\text { Chen, 2016: } \\
\text { 122-132) }\end{array}$ \\
\hline $\begin{array}{l}\text { Alkan, } \\
\text { Gönül }\end{array}$ & 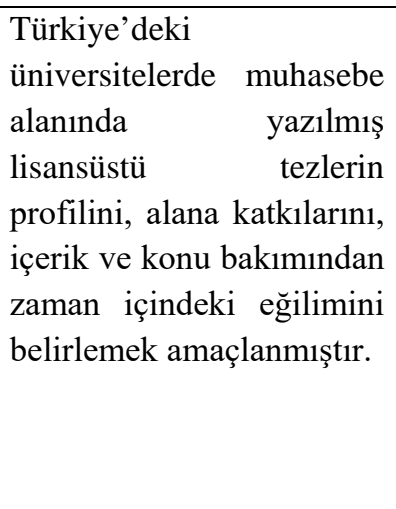 & $\begin{array}{l}\text { 2003-2006 yıllarında hazırlanan } \\
\text { tezlerin büyük çoğunluğu, TFRS } \\
8 \text { Faaliyet Bölümleri, UFRS ile } \\
\text { TDHP' nın karşılaştırılması, } \\
\text { KOBİ UFRS, TMS } 41 \text { Tarımsal } \\
\text { Faaliyetler ve } \\
\text { işletmelerinde TMS/TFRS' nin } \\
\text { maliyet sistemlerine etkileri, TMS } \\
23 \text { Borçlanma Maliyetleri, TMS } \\
12 \quad \text { Ertelenmiş } \\
\text { Uygulamaları, TMS } 1 \text { Mergi }\end{array}$ & $\begin{array}{l}\text { Ulusal } \\
\text { makale }\end{array}$ & $\begin{array}{l}\text { (Alkan, } \\
\text { 2014: 41-52) }\end{array}$ \\
\hline
\end{tabular}




\begin{tabular}{|c|c|c|c|c|}
\hline & & $\begin{array}{l}\text { Tabloların Sunumu konularında } \\
\text { hazırlanmıştır. } \\
\text { Tezlerin büyük çoğunluğu (491 } \\
\text { adet) 2001-2012 döneminde } \\
\text { hazırlanmıştır. Muhasebe alanında } \\
\text { yapılan tezlerin \%25'i Marmara } \\
\text { Üniversitesi’nde hazırlanmıştır. } \\
\text { İşletme bölümü bulunan birçok } \\
\text { üniversitede muhasebe alanında } \\
\text { tez yapılmamaktadır. } \\
\text { Muhasebe eğitimi alanında } \\
\text { hazırlanan tezler Ticaret Meslek } \\
\text { Liseleri'ndeki muhasebe eğitimi } \\
\text { üzerine yapılan araştırmaları } \\
\text { kapsamaktadır. }\end{array}$ & & \\
\hline $\begin{array}{l}\text { Zan, Burcu } \\
\text { Umut }\end{array}$ & 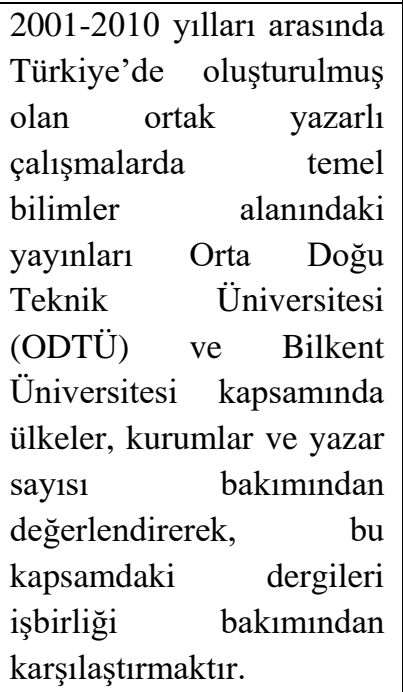 & $\begin{array}{l}\text { 2001-2010 yılları arasında } \\
\text { Türkiye'de oluşturulan makaleler } \\
\text { temel alınarak karşılaştırma } \\
\text { yapıldığında, WoS ve Scopus veri } \\
\text { tabanlarında yapısal farklılıklar } \\
\text { bulunduğu saptanmıştır. Bununla } \\
\text { birlikte her iki veri tabanından } \\
\text { elde edilen sonuçlar } \\
\text { değerlendirildiğinde, Türkiye'nin } \\
\text { uluslararası ortak yazarlı çalışma } \\
\text { oranının dünya ortalamasının } \\
\text { altında olduğu belirlenmiştir. }\end{array}$ & $\begin{array}{l}\text { Yüksek } \\
\text { lisans tezi }\end{array}$ & $\begin{array}{l}\text { (Zan, 2012: } \\
1-246)\end{array}$ \\
\hline $\begin{array}{l}\text { Fülbier, } \\
\text { Rolf Uwe } \\
\& \quad \text { Weller, } \\
\text { Manuel }\end{array}$ & $\begin{array}{l}\text { Almanya'da muhasebe } \\
\text { alanında önde gelen } \\
\text { akademik dergilerin, } \\
\text { 1950-2005 yıllarına ilişkin } \\
\text { bibliyometrik analiz } \\
\text { yöntemi ile bir yayın atıf } \\
\text { analizinin } \\
\text { gerçekleştirilmesi } \\
\text { amaçlanmıştır. }\end{array}$ & $\begin{array}{l}\text { Almanya'da Alman finansal } \\
\text { muhasebesine ilişkin bir yayın atıf } \\
\text { analizinin gerçekeleştrildiği } \\
\text { çalışmada elde edilen bulgular } \\
\text { şunlardır: } 1990 \text { öncesinde } \\
\text { yayınların bir çoğu çok yazarlıdır, } \\
\text { almanca dili yayınlarda ağırlıklı } \\
\text { olarak kullanılmıştır. Akademik } \\
\text { çalışmaların birçoğu kitaplar, } \\
\text { uygulama dergilerinden, yasal ve } \\
\text { yargısal kaynaklardan } \\
\text { oluşmaktadır. Bununla birlikte } \\
\text { 1990 sonrasında ingilizce } \\
\text { yayınların, makale başına } \\
\text { ingilizce referansların ve dili } \\
\text { almanca olmayan akademik } \\
\begin{array}{l}\text { dergilerin sayısı artmıştır. Ayrıca } \\
\text { araştırmadan elde edilen bulgular }\end{array}\end{array}$ & $\begin{array}{l}\text { Uluslararası } \\
\text { makale }\end{array}$ & $\begin{array}{l}\text { (Fülbier ve } \\
\text { Weller, } \\
\text { 2011: 2-33) }\end{array}$ \\
\hline
\end{tabular}




\begin{tabular}{|c|c|c|c|c|}
\hline & & 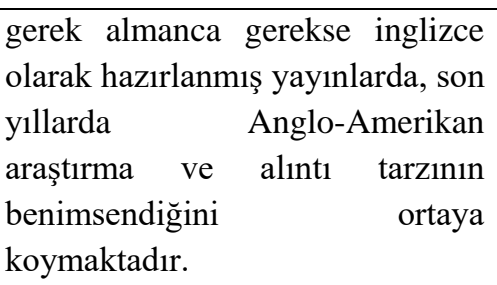 & & \\
\hline $\begin{array}{l}\text { Cardoso, } \\
\text { Ricardo } \\
\text { Lopes \& } \\
\text { Oyadomari, } \\
\text { José Carlos } \\
\text { T. \& Neto, } \\
\text { Octavio } \\
\text { Ribeiro de } \\
\text { Mendonça }\end{array}$ & 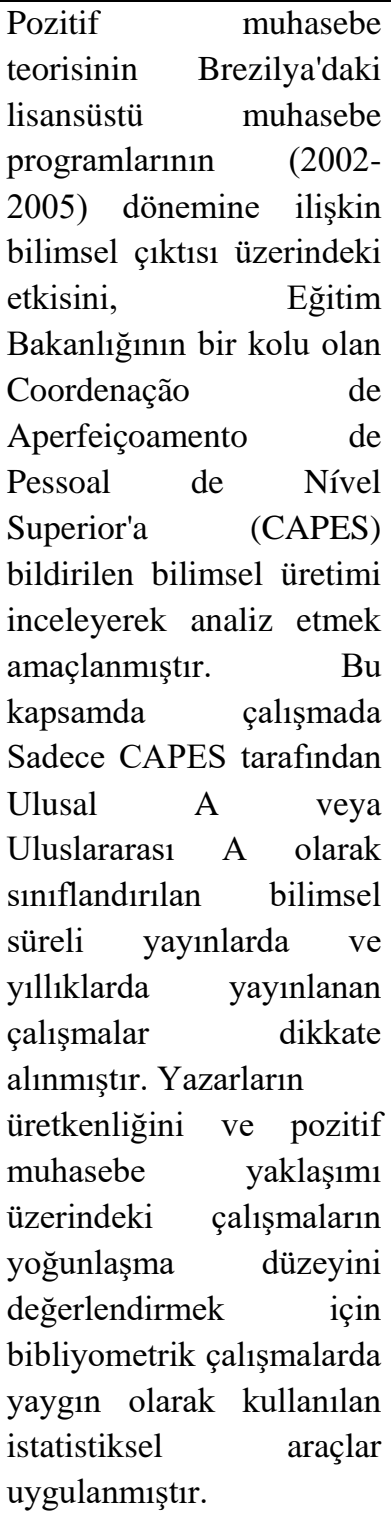 & 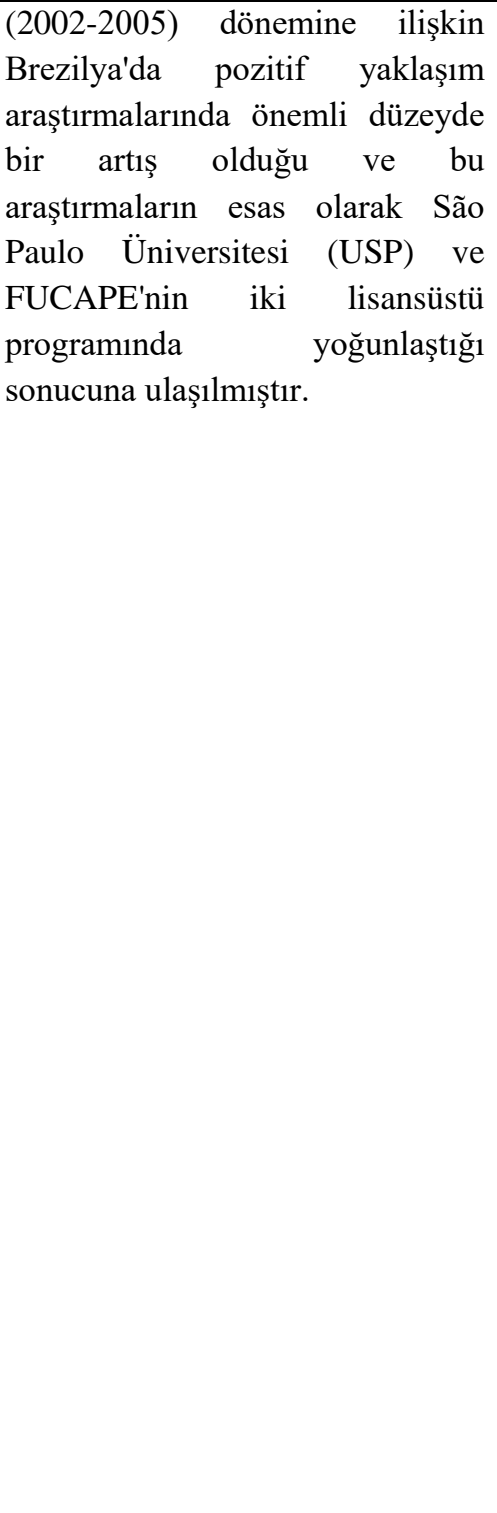 & $\begin{array}{l}\text { Uluslararası } \\
\text { makale }\end{array}$ & $\begin{array}{l}\text { Cardoso, } \\
\text { Oyadomari } \\
\text { ve Neto, } \\
\text { 2007: } 149- \\
161)\end{array}$ \\
\hline
\end{tabular}

Çalışma kapsamında YÖK Ulusal Tez Merkezi'nde sunulmuş, muhasebe standartlar ile finansal raporlama standartları kapsamındaki lisansüstü tezlerin incelenmesinde ele alınan bibliyometrik analiz yöntemi ile sağlanacak katkılar aşağıda sunulmuştur;

- Farklı üniversiteler bünyesinde muhasebe standartları ile finansal raporlama standartları konusunda hazırlanan ve YÖK Ulusal Tez Merkezi'nde sunulmuş lisansüstü tezler türleri, erişim imkanı, özgün dilleri, danışman unvanları, bünyesinde hazırlandıkları 
anabilim dalı, hazırlanan lisansüstü tezlerde kullanılan veri toplama yöntemi ve tez konuları bakımından sayısal olarak sınıflandırılmıştır.

- Çalışma kapsamında muhasebe standartları ile finansal raporlama standartları kapsamında, yüksek lisans tezleri ve doktora tezlerinde en çok çalışılan konular ve herhangi bir lisansüstü tez çalışmasına konu olmadığı saptanan standartlar belirlenmiştir. Bu kapsamda yapılan bibliyometrik analizde Muhasebe Standartlar1-Finansal Raporlama Standartları kapsamında doktora tezlerinin, ağırlıklı olarak TMS/TFRS ve VUK'da ve yer alan değerleme esaslarının karşılaştırılması ile Avrupa'daki muhasebe standartlarının Türkiye muhasebe standartları ile karşılaştırılması konularında yazıldığı saptanmıştır. Yüksek lisans tezlerinin ise ağırlıklı olarak UMS 2 stoklar standardı ile standartlara göre türev finansal araçların muhasebeleştirilmesi ve incelenmesi konularında yazıldığı saptanmıştır. Ayrıca herhangi bir lisansüstü tez çalışmasına konu olmamış üç adet standart saptanmıştır. Bunlar "TFRS 6 Maden Kaynaklarının Araştırılması ve Değerlendirilmesi”, “TFRS 14 Düzenlemeye Dayalı Erteleme Hesapları", "TMS 26 Emeklilik Fayda Planlarında Muhasebeleştirme ve Raporlama" standartlarıdır.

$\mathrm{Bu}$ bağlamda çalışmanın amacı, ülkemizde muhasebe standartları ile finansal raporlama standartları kapsamında hazırlanmış ve YÖK Ulusal Tez Merkezi'nin resmi internet sitesinde sunulmuş lisansüstü tezleri bibliyometrik analiz yöntemi ile incelemek, çeşitli ölçütler bakımından sınıflandırmak ve muhasebe standartları ile finansal raporlama standartları kapsamında üzerine en çok lisansüstü tez yazılan ve hiç lisansüstü tez yazılmayan standartları belirlemektir.

\section{METODOLOJÍ}

\subsection{Araştırmanın Amacı ve Kapsamı}

$\mathrm{Bu}$ araştırmanın amacı küresel anlamda ortak bir muhasebe dilinin oluşturulmasında büyük önem taşıyan, muhasebe standartları ve finansal raporlama standartları kapsamında Türkiye'de yazılmış lisansüstü tezlerin gelişimi incelemek amacıyla bibliyometrik bir analiz sunmaktır. Bu kapsamda 19.09.2020 tarihine kadar, Yüksek Öğretim Kurumu (YÖK) Ulusal Tez Merkezi'nde erişime sunulmuş bulunan lisansüstü tezler, bünyesinde hazırlandığı üniversite, anabilim dalı, erişim imkanı, tamamlanma yılı, tezin türü, tezin yayımlandığı dil, bünyesinde hazırlandığı danışman unvanı, veri toplama yöntemi ve tezin konusu ve benzeri ölçütler kapsamında incelenmiş ve elde edilen sonuçlar yorumlanmıştır. Çalışma kapsamında ayrıca YÖK Ulusal Tez Merkezi'nde erişim kısıtı bulunan tezlere ilişkin sunulmuş özet bilgiler de çalışmaya dahil edilmiştir.

\subsection{Araştırmanın Yöntemi}

Araştırma kapsamında YÖK Ulusal Tez Merkezi'nde sunulmuş lisansüstü tezlerin içeriğgine ilişkin analizde bibliyometrik analiz yöntemi kullanılmıştır. Bibliyometri, bilimsel disiplinde materyali nicel olarak ele alan temel bir bilgi bilimi alanıdır. Bu araştırma yöntemi, belli bir alandaki araştırmaları ve bu araştırmaların zaman içerisindeki eğilimlerini belirlemede oldukça fayda sağlamaktadır (Merigó ve Yang, 2017: 71). Literatürde yer alan bilgilere göre Bibliyometri ilk kez 1917 yılında Cole ve Eales tarafından oluşturulmuş ve söz konusu çalışmada, 1550-1850 yılları arasında anatomi alanında yayınlanmış akademik 
çalışmalar karşılaştırılarak istatistiki bir yöntemle analiz edilmiştir. 1927 yılında P.L.K Gross ve E.M. Gross'un Journal Of The American Chemical Society' de yayınlanan makalelerin kaynakçalarını analiz ettikleri çalışmaları ise atıf analizinin yapıldığı ilk çalışma olarak kabul edilmektedir. Ulusal literatür taramasından elde edilen sonuçlar ise Türkiye’de bibliyometrik analiz yönteminin kullanıldığı ilk çalışmanın 1970 yılında Özinönü tarafından oluşturulmuş olduğunu ve ilgili çalışmada fizik, kimya, biyoloji, matematik, yer bilimleri alanlarındaki bilimsel verimliliğin ölçülmesinin amaçlandığını ortaya koymaktadır (Lawani, 1981: 294295). Özellikle 1990 yılından sonra artış gözlenen bibliyometrik analiz yöntemi (Al, 2008:10) akademik çalışmalarda araştırma yöntemi olarak halen yaygın olarak kullanılmaktadır.

\subsection{Anakütle ve Örneklem}

Araştırmanın anakütlesini, Türkiye'de muhasebe standartları ve finansal raporlama standartları kapsamında yazılmış ve YÖK Ulusal Tez Merkezi'nde sunulmuş 468 lisansüstü tez oluşturmaktadır. Bu tezlere YÖK Ulusal Tez Merkezi'nden "muhasebe standartları", "finansal raporlama standartları", "accounting standards" (özgün dili İngilizce olan tezler için), "financial reporting standards" (özgün dili İngilizce olan tezler için), "TMS-TFRS", "UMS-UFRS” (özgün dili Türkçe olan tezler için), "IAS-IFRS” anahtar kelimeleri ile arama yapılarak ulaşılmıştır. Araştırma kapsamında erişim izni bulanan tezlerin içeriği ile ilgili bilgilere ulaşılabilmiş ancak erişim yasağı bulunan 45 adet tezin içeriğine ilişkin bilgiler tezlerin özetlerinden ve YÖK Ulusal Tez Merkezi'nde sunulmuş diğer bilgilerinden sağlanmaya çalışılmıştır. Araştırmanın örneklemini oluşturan lisansüstü tezlere ilişkin bilgiler aşağıda Tablo 2'de sunulmuştur.

Tablo 2. Muhasebe Standartları ile Finansal Raporlama Standartları Kapsamındaki Lisansüstü Tezlerin Yıllara ve Türüne Göre Dağılımı

\begin{tabular}{|l|l|l|l|l|l|l|}
\hline Yıllar & $\begin{array}{l}\text { Doktora } \\
\text { Tezi }\end{array}$ & $\begin{array}{l}\text { Doktora } \\
\text { Tezi \% }\end{array}$ & $\begin{array}{l}\text { Yüksek } \\
\text { Lisans Tezi }\end{array}$ & $\begin{array}{l}\text { Yüksek Lisans } \\
\text { Tezi \% }\end{array}$ & $\begin{array}{l}\text { Toplam } \\
\text { Lisansüstü } \\
\text { Tez }\end{array}$ & $\begin{array}{l}\text { Toplam } \\
\text { Lisansüstü } \\
\text { Tez \% }\end{array}$ \\
\hline 1992 & 1 & 1,03 & - & - & 1 & 0,21 \\
\hline 1993 & - & - & - & - & - & - \\
\hline 1994 & - & - & 1 & 0,27 & 1 & 0,21 \\
\hline 1995 & - & - & 2 & 0,54 & 2 & 0,43 \\
\hline 1996 & - & - & 2 & 0,54 & 2 & 0,43 \\
\hline 1997 & 1 & 1,03 & - & - & 1 & 0,21 \\
\hline 1998 & - & - & 3 & 0,81 & 3 & 0,64 \\
\hline 1999 & - & - & 2 & 0,54 & 2 & 0,43 \\
\hline 2000 & 1 & 1,03 & 2 & 0,54 & 3 & 0,64 \\
\hline 2001 & 2 & 2,06 & 4 & 1,08 & 6 & 1,28 \\
\hline 2002 & - & - & 5 & 1,35 & 5 & 1,07 \\
\hline 2003 & 1 & 1,03 & 7 & 1,89 & 8 & 1,71 \\
\hline 2004 & - & - & 2 & 0,54 & 2 & 0,43 \\
\hline 2005 & 3 & 3,09 & 8 & 2,16 & 11 & 2,35 \\
\hline 2006 & 2 & 2,06 & 17 & 4,58 & 19 & 4,06 \\
\hline 2007 & 2 & 2,06 & 20 & 5,39 & 22 & 4,70 \\
\hline 2008 & 4 & 4,12 & 16 & 4,31 & 20 & 4,27 \\
\hline 2009 & 7 & 7,22 & 23 & 6,20 & 30 & 6,41 \\
\hline 2010 & 8 & 8,25 & 28 & 7,55 & 36 & 7,69 \\
\hline & & & & & \\
\hline
\end{tabular}




\begin{tabular}{|l|l|l|l|l|l|l|}
\hline 2011 & 2 & 2,06 & 15 & 4,04 & 17 & 3,63 \\
\hline 2012 & 5 & 5,15 & 12 & 3,23 & 17 & 3,63 \\
\hline 2013 & 5 & 5,15 & 21 & 5,66 & 26 & 5,56 \\
\hline 2014 & 5 & 5,15 & 21 & 5,66 & 26 & 5,56 \\
\hline 2015 & 8 & 8,25 & 27 & 7,28 & 35 & 7,48 \\
\hline 2016 & 11 & 11,34 & 28 & 7,55 & 39 & 8,33 \\
\hline 2017 & 5 & 5,15 & 30 & 8,09 & 35 & 7,48 \\
\hline 2018 & 14 & 14,43 & 23 & 6,20 & 37 & 7,91 \\
\hline 2019 & 9 & 9,28 & 49 & 13,21 & 58 & 12,39 \\
\hline 2020 & 1 & 1,03 & 3 & 0,81 & 4 & 0,85 \\
\hline Toplam & $\mathbf{9 7}$ & $\mathbf{1 0 0}$ & $\mathbf{3 7 1}$ & $\mathbf{1 0 0}$ & $\mathbf{4 6 8}$ & $\mathbf{1 0 0}$ \\
\hline
\end{tabular}

Tablo 2'de lisansüstü tezlerin 97'sinin doktora, 371'inin ise yüksek lisans düzeyinde olduğu görülmektedir. Lisansüstü tezlerin yıllara göre dağılımı incelendiğinde, hem doktora hem de yüksek lisans tezlerinin 2005 yılından sonra sayıca arttığı ve toplam lisansüstü tez sayısının en fazla 2019 yılında gerçekleştiği görülmektedir. Dolayısıyla ülkemizde hazırlanan lisansüstü tezlerin yıllar itibariyle sayıca arttığını söylemek mümkündür.

\section{ARAȘTIRMANIN BULGULARI}

Ülkemizde AB'ye uyum sürecinde karşımıza çıkan ve muhasebe uygulamalarımızda esas alınmak üzere Türkçeye TMS/TFRS olarak çevrilen standartlar, halka açık faaliyet gösteren şirketlerin muhasebe uygulamalarında esas alınmaları üzere Resmi Gazete 'de yayımlanarak yürürlüğe girmiştir. Bu muhasebe ve finansal raporlama standartları, pek çok alanda olduğu gibi, ulusal alanda yazılan lisansüstü tezlerde araştırma konusu olarak da etkisini göstermektedir. Bu çalışma kapsamında da ülkemizde 2020 yılının Eylül ayına kadar yazılmış olan muhasebe standartları ile finansal raporlama standartları kapsamındaki lisansüstü tezler incelenmiş ve ülkemizde yazılmış olan bu tezler bibliyometrik yöntemle analiz edilerek muhasebe ve finansal raporlama standartlarının ülkemizdeki gelişimi incelenmiştir. $\mathrm{Bu}$ araştırma kapsamında elde edilen bulgular aşağıda tablolar eşliğinde sunulmuştur.

Tablo 3. Muhasebe Standartları ile Finansal Raporlama Standartları Kapsamındaki Lisansüstü Tezlerin Bünyesinde Hazırlandıkları Üniversitelere Göre Dağılımı

\begin{tabular}{|l|l|l|l|l|}
\hline Üniversiteler & Doktora Tezi & $\begin{array}{l}\text { Doktora } \\
\text { Tezi \% }\end{array}$ & $\begin{array}{l}\text { Yüksek } \\
\text { Lisans Tezi }\end{array}$ & $\begin{array}{l}\text { Yüksek Lisans } \\
\text { Tezi \% }\end{array}$ \\
\hline Marmara Üniversitesi & 20 & 20,62 & 87 & 23,08 \\
\hline Gazi Üniversitesi & 8 & 8,25 & 29 & 7,69 \\
\hline Dokuz Eylül Üniversitesi & 7 & 7,22 & 13 & 3,45 \\
\hline Ankara Üniversitesi & 6 & 6,19 & 2 & 0,53 \\
\hline Başkent Üniversitesi & 4 & 4,12 & 8 & 2,12 \\
\hline Anadolu Üniversitesi & 4 & 4,12 & 2 & 0,53 \\
\hline Süleyman Demirel Üniversitesi & 3 & 3,09 & 14 & 3,71 \\
\hline Sakarya Üniversitesi & 3 & 3,09 & 4 & 1,06 \\
\hline Niğde Üniversitesi & 3 & 3,09 & 4 & 1,06 \\
\hline İnönü Üniversitesi & 3 & 3,09 & 2 & 0,53 \\
\hline Pamukkale Üniversitesi & 3,09 & 1 & 0,27 \\
\hline İstanbul Üniversitesi & 3 & 2,06 & 12 & 3,18 \\
\hline Kocaeli Üniversitesi & 2 & 2,06 & 9 & 2,39 \\
\hline Afyon Kocatepe Üniversitesi & 2 & 2,06 & 5 & 1,33 \\
\hline Karadeniz Teknik Üniversitesi & 2 & 2,06 & 5 & 1,33 \\
\hline
\end{tabular}


The Journal of Accounting and Finance- October 2021

(92): 115-138

\begin{tabular}{|c|c|c|c|c|}
\hline Kırıkkale Üniversitesi & 2 & 2,06 & 2 & 0,53 \\
\hline İzmir Ekonomi Üniversitesi & 2 & 2,06 & 2 & 0,53 \\
\hline Dicle Üniversitesi & 2 & 2,06 & 1 & 0,27 \\
\hline Kadir Has Üniversitesi & 2 & 2,06 & 1 & 0,27 \\
\hline İstanbul Ticaret Üniversitesi & 1 & 1,03 & 12 & 3,18 \\
\hline Selçuk Üniversitesi & 1 & 1,03 & 9 & 2,39 \\
\hline Uludağ Üniversitesi & 1 & 1,03 & 9 & 2,39 \\
\hline Kütahya Dumlupınar Üniversitesi & 1 & 1,03 & 5 & 1,33 \\
\hline Sivas Cumhuriyet Üniversitesi & 1 & 1,03 & 4 & 1,06 \\
\hline Manisa Celal Bayar Üniversitesi & 1 & 1,03 & 4 & 1,06 \\
\hline $\begin{array}{lll}\text { Kahramanmaraş } & \text { Sütçü } & \text { İmam } \\
\text { Üniversitesi } & & \\
\end{array}$ & 1 & 1,03 & 3 & 0,80 \\
\hline Akdeniz Üniversitesi & 1 & 1,03 & 3 & 0,80 \\
\hline İstanbul Okan Üniversitesi & 1 & 1,03 & 2 & 0,53 \\
\hline Hacettepe Üniversitesi & 1 & 1,03 & 2 & 0,53 \\
\hline Erciyes Üniversitesi & 1 & 1,03 & 2 & 0,53 \\
\hline Çukurova Üniversitesi & 1 & 1,03 & 2 & 0,53 \\
\hline Galatasaray Üniversitesi & 1 & 1,03 & 1 & 0,27 \\
\hline Aksaray Üniversitesi & 1 & 1,03 & 1 & 0,27 \\
\hline Nevşehir Hacı Bektaş Veli Üniversitesi & 1 & 1,03 & - & - \\
\hline Yaşar Üniversitesi & 1 & 1,03 & - & - \\
\hline Düzce Üniversitesi & 1 & 1,03 & - & - \\
\hline Okan Üniversitesi & - & - & 23 & 6,10 \\
\hline İstanbul Aydın Üniversitesi & - & - & 9 & 2,39 \\
\hline Işık Üniversitesi & - & - & 9 & 2,39 \\
\hline Mehmet Akif Ersoy Üniversitesi & - & - & 7 & 1,86 \\
\hline Balıkesir Üniversitesi & - & - & 6 & 1,59 \\
\hline Hitit Üniversitesi & - & - & 3 & 0,80 \\
\hline Kafkas Üniversitesi & - & - & 3 & 0,80 \\
\hline İstanbul Arel Üniversitesi & - & - & 3 & 0,80 \\
\hline Niğde Ömer Halisdemir Üniversitesi & - & - & 3 & 0,80 \\
\hline Gaziantep Üniversitesi & - & - & 3 & 0,80 \\
\hline Haliç Üniversitesi & - & - & 3 & 0,80 \\
\hline Ortadoğu Teknik Üniversitesi & - & - & 3 & 0,80 \\
\hline Çanakkale Onsekiz Mart Üniversitesi & - & - & 3 & 0,80 \\
\hline Bilecik Șeyh Edebali Üniversitesi & - & - & 2 & 0,53 \\
\hline Tokat Gaziosmanpaşa Üniversitesi & - & - & 2 & 0,53 \\
\hline Hasan Kalyoncu Üniversitesi & - & - & 2 & 0,53 \\
\hline Atatürk Üniversitesi & - & - & 2 & 0,53 \\
\hline Türk Hava Kurumu Üniversitesi & - & - & 2 & 0,53 \\
\hline Koç Üniversitesi & - & - & 2 & 0,53 \\
\hline Yalova Üniversitesi & - & - & 2 & 0,53 \\
\hline Yüzüncü Y1l Üniversitesi & - & - & 2 & 0,53 \\
\hline Avrasya Üniversitesi & - & - & 2 & 0,53 \\
\hline Adnan Menderes Üniversitesi & - & - & 1 & 0,27 \\
\hline Bahçeşehir Üniversitesi & - & - & 1 & 0,27 \\
\hline Muğla Sitk1 Koçman Üniversitesi & - & - & 1 & 0,27 \\
\hline Trakya Üniversitesi & - & - & 1 & 0,27 \\
\hline Zonguldak Karaelmas Üniversitesi & - & - & 1 & 0,27 \\
\hline Bayburt Üniversitesi & - & - & 1 & 0,27 \\
\hline Bülent Ecevit Üniversitesi & - & - & 1 & 0,27 \\
\hline Gediz Üniversitesi & - & - & 1 & 0,27 \\
\hline İzmir Katip Çelebi Üniversitesi & - & - & 1 & 0,27 \\
\hline Bozok Üniversitesi & - & - & 1 & 0,27 \\
\hline
\end{tabular}




\begin{tabular}{|l|l|l|l|l|}
\hline Kahramanoğlu Mehmetbey Üniversitesi & - & - & 1 & 0,27 \\
\hline Mersin Üniversitesi & - & - & 1 & 0,27 \\
\hline Toros Üniversitesi & - & - & 1 & 0,27 \\
\hline Y1ldız Teknik Üniversitesi & - & - & 1 & 0,27 \\
\hline Karamanoğlu Mehmetbey Üniversitesi & - & - & 1 & 0,27 \\
\hline Kayseri Üniversitesi & - & - & 1 & 0,27 \\
\hline Kırgıistan-Türkiye Manas Üniversitesi & - & - & 1 & 0,27 \\
\hline Ufuk Üniversitesi & - & - & 1 & 0,27 \\
\hline Necmettin Erbakan Üniversitesi & - & - & 1 & 0,27 \\
\hline Toplam & 97 & 100 & 371 & 100 \\
\hline
\end{tabular}

Tablo 3'te muhasebe standartları ile finansal raporlama standartları konusundaki lisansüstü tezlerin bünyesinde hazırlandıkları 77 üniversitenin bir listesi sunulmuştur. Buna göre ilgili konuda en fazla tez çalışması yapılan üniversite, 20 doktora ve 87 yüksek lisans tezi ile Marmara Üniversitesi'dir. İkinci sırada 8 doktora tezi ve 29 yüksek lisans tezi ile Gazi Üniversitesi gelmekte, onu 7 doktora tezi ile dokuz eylül üniversitesi ve 23 yüksek lisans tezi ile Okan Üniversitesi takip etmektedir. Ayrıca Tablo 3'teki veriler yüzdelik dilim açısından değerlendirildiğinde, muhasebe standartları ile finansal raporlama standartları konusunda yazılmış doktora tezlerinin yüzde 20,62'sinin ve yüksek lisans tezlerinin yüzde 23,08'inin Marmara Üniversitesi bünyesinde hazırlanmış olduğu görülmektedir.

Tablo 4. Muhasebe Standartları ile Finansal Raporlama Standartları Kapsamındaki Lisansüstü Tezlerin Erişim İmkanı Bakımından Dağılımı

\begin{tabular}{|l|l|l|l|l|}
\hline Lisansüstü Teze Erişim İmkanı & Doktora Tezi & $\begin{array}{l}\text { Doktora Tezi } \\
\text { \% }\end{array}$ & $\begin{array}{l}\text { Yüksek Lisans } \\
\text { Tezi }\end{array}$ & $\begin{array}{l}\text { Yüksek Lisans } \\
\text { Tezi \% }\end{array}$ \\
\hline Erişime Açık Tez Sayısı & 86 & 88,66 & 337 & 90,84 \\
\hline Erişimi Kısıtlı Tez Sayısı & 11 & 11,34 & 34 & 9,16 \\
\hline Toplam & 97 & 100 & 371 & 100 \\
\hline
\end{tabular}

Tablo 4'te sunulmuş verilerden, YÖK Ulusal Tez Merkezi'nin resmi internet sitesinde, muhasebe standartları ile finansal raporlama standartları konusundaki lisansüstü tezlerinden, doktora tezlerinin yüzde 11,34'üne ve yüksek lisans tezlerinin yüzde 9,16'sına erişim kısıt bulunduğu görülmektedir. Ayrıca yüksek lisans tezlerine oranla daha az sayıda doktora tezi yazılmış olmasına rağmen, doktora tezlerine erişim kısıtı, yüksek lisans tezlerine oranla daha yüksektir. $\mathrm{Bu}$ durum muhasebe standartları ile finansal raporlama standartları konusunda doktora tezlerine oranla yüksek lisans tezlerinin daha fazla atıf alabilmelerine neden olabilmektedir.

Tablo 5. Muhasebe Standartları ile Finansal Raporlama Standartları Kapsamındaki Lisansüstü Tezlerin Özgün Dilleri Bakımından Dağılımı

\begin{tabular}{|l|l|l|l|l|}
\hline $\begin{array}{l}\text { Tezlerin Öz Ö̈n } \\
\text { Dilleri }\end{array}$ & Doktora Tezi & Doktora Tezi \% & $\begin{array}{l}\text { Yüksek Lisans } \\
\text { Tezi }\end{array}$ & $\begin{array}{l}\text { Yüksek Lisans } \\
\text { Tezi \% }\end{array}$ \\
\hline Türkçe & 88 & 90,72 & 354 & 95,42 \\
\hline İnilizce & 7 & 7,22 & 13 & 3,50 \\
\hline Almanca & 2 & 2,06 & 4 & 1,08 \\
\hline Toplam & 97 & 100 & 371 & 100 \\
\hline
\end{tabular}

Tablo 5'te muhasebe standartları ile finansal raporlama standartları konusundaki lisansüstü tezlerin özgün dillerine ilişkin bilgiler sunulmuştur. Tabloya göre doktora tezlerinin 
yüzde 90,72'si Türkçe yazılmış iken, yüzde 7, 22'si İngilizce ve yüzde 2,06's1 Almanca yazılmıştır. Yüksek lisans tezlerinin ise yüzde 95,42'si Türkçe, yüzde 3,5'i İngilizce ve yüzde 1,08 'i ise Almaca yazılmıştır. Tablodan elde edilen sonuçlar ülkemizde yabancı dilde yazılan tezlerin sayıca oldukça az olduğunu ortaya koymaktadır.

Tablo 6. Muhasebe Standartları ile Finansal Raporlama Standartları Kapsamında Yabancı Dilde Yazılan Tezlerin Üniversitelere Göre Dağılımları

\begin{tabular}{|l|l|l|l|l|l|}
\hline Üniversiteler & $\begin{array}{l}\text { Tezin Özgün } \\
\text { Dili }\end{array}$ & $\begin{array}{l}\text { Doktora } \\
\text { Tezi }\end{array}$ & $\begin{array}{l}\text { Doktora } \\
\text { Tezi \% }\end{array}$ & $\begin{array}{l}\text { Yüksek } \\
\text { Lisans Tezi }\end{array}$ & $\begin{array}{l}\text { Yüksek Lisans } \\
\text { Tezi \% }\end{array}$ \\
\hline Marmara Üniversitesi & İngilizce & 5 & 55,56 & 4 & 23,53 \\
\hline Marmara Üniversitesi & Almanca & 2 & 22,22 & 4 & 23,53 \\
\hline İstanbul Okan Üniversitesi & İngilizce & 1 & 11,11 & - & - \\
\hline Kırıkkale Üniversitesi & İngilizce & 1 & 11,11 & - & - \\
\hline $\begin{array}{l}\text { Orta Döngău } \\
\text { Üniversitesi }\end{array}$ & İngilizce & - & - & 4 & 23,53 \\
\hline Dokuz Eylül Üniversitesi & İngilizce & - & - & 1 & 5,88 \\
\hline İzmir Ekonomi Üniversitesi & İngilizce & - & - & 1 & 5,88 \\
\hline Koç Üniversitesi & İngilizce & - & - & 1 & 5,88 \\
\hline Bursa Uludağ Üniversitesi & İngilizce & - & - & 1 & 5,88 \\
\hline Balıkesir Üniversitesi & İngilizce & - & - & 1 & 5,88 \\
\hline Toplam & & 9 & 100 & 17 & 100 \\
\hline
\end{tabular}

Tablo 6'da muhasebe standartları ile finansal raporlama standartları konusunda yabancı dilde yazılan lisansüstü tezlerin, türüne ve üniversitelere göre dağılımlarına ilişkin bilgiler sunulmuştur. Buna göre İngilizce özgün dilinde en fazla doktora tezi yüzde 55,56'l1k pay ile Marmara Üniversitesinde, en fazla yüksek lisans tezi ise yine yüzde 23,53'lük pay ile Marmara Üniversitesi ve yüzde 23,53'lük pay ile Orta Doğu Teknik Üniversitesi bünyesinde hazırlanmıştır. Yabancı bir dilde hazırlanan doktora tezlerinin yüzde 22,22'si ve yabancı bir dilde hazırlanan yüksek lisans tezlerinin yüzde 23,53'ü ise Almanca özgün dilinde hazırlanmıştır. Ayrıca Almanca özgün dilinde hazırlanan tüm doktora ve yüksek lisans tezleri Marmara Üniversitesi bünyesinde hazırlanmıştır. Tablodan elde edilen bu sonuçlar ülkemizde yabancı bir dilde yazılan tezlerin az bir düzeyde bulunması ile birlikte bu tezlerin çoğunun İngilizce dilinde yazıldığını ve bu tezlerin, muhasebe standartları ile finansal raporlama standartları konusunda en fazla lisansüstü tez yazılan üniversite olan Marmara Üniversitesi bünyesinde yazıldığını ortaya koymaktadır. Dolayısıyla muhasebe standartları ile finansal raporlama standartları konusunda, Türkçe, İngilizce ve Almanca dilinde hazırlanan lisansüstü tezlerin tamamının en fazla Marmara Üniversitesi bünyesinde hazırlanmış olduğunu söylemek mümkündür.

Tablo 7. Muhasebe Standartları ile Finansal Raporlama Standartları Kapsamındaki Lisansüstü Tezlerin Danışman Unvanları Bakımından Dağılımı

\begin{tabular}{|c|c|c|c|c|}
\hline Tez Danışman Unvanı & Doktora Tezi & Doktora Tezi \% & $\begin{array}{l}\text { Yüksek Lisans } \\
\text { Tezi }\end{array}$ & $\begin{array}{l}\text { Yüksek Lisans Tezi } \\
\%\end{array}$ \\
\hline Prof. Dr. & 67 & 69,07 & 130 & 35,04 \\
\hline Doç. Dr. & 21 & 21,65 & 158 & 42,59 \\
\hline Dr. Öğr. Üyesi & 9 & 9,28 & 83 & 22,37 \\
\hline Toplam & 97 & 100 & 371 & 100 \\
\hline
\end{tabular}


Tablo 7'de muhasebe standartları ile finansal raporlama standartları konusundaki lisansüstü tezlerin, danışman unvanlarına ilişkin bilgiler sunulmuştur. Buna göre doktora tezlerinin yüzde 69,07’si Prof. Dr. ve yüksek lisans tezlerinin ise yüzde 42,59'u Doç. Dr. unvanına sahip akademisyenler danışmanlığında hazırlanmıştır. Ayrıca muhasebe standartları ile finansal raporlama standartları konusundaki lisansüstü tezlerin toplamda 197'si Prof. Dr., 179'u Doç. Dr. ve 92'si ise Yrd. Doç. Dr. unvanına sahip akademisyenler ile bu unvanın 7100 Sayılı Yükseköğretim Kanunu ile dönüştürülmesi neticesinde Dr. Öğr. Üyesi unvanına sahip akademisyenler danışmanlığında hazırlanmıştır. Dolayısıyla bu veriler ışığında, doktora aşamasında bulunan öğrencilerin genellikle, tezlerini bu alanda profesörlük unvanına sahip akademisyenler eşliğinde hazırlamayı tercih ettiklerini söylemek mümkündür.

Tablo 8. Muhasebe Standartları ile Finansal Raporlama Standartları Kapsamındaki Lisansüstü Tezlerin Anabilim Dallarına Göre Dağılımı

\begin{tabular}{|l|l|l|l|l|}
\hline Anabilim Dalları & Doktora Tezi & Doktora Tezi \% & $\begin{array}{l}\text { Yüksek Lisans } \\
\text { Tezi }\end{array}$ & $\begin{array}{l}\text { Yüksek Lisans Tezi } \\
\text { \% }\end{array}$ \\
\hline İşletme & 86 & 88,66 & 320 & 86,25 \\
\hline Maliye & 3 & 3,09 & 25 & 6,74 \\
\hline Bankacılık & 2 & 2,06 & 7 & 1,89 \\
\hline Kamu Yönetimi & 2,06 & - & - \\
\hline Ekonomi & 2 & 1,03 & 6 & 1,62 \\
\hline Uluslararası İlişkiler & 1 & 1,03 & - & - \\
\hline Ziraat & 1 & 1,03 & - & - \\
\hline Sigortacılık & 1 & 1,03 & 3 & 0,81 \\
\hline Hukuk & - & - & 3 & 0,81 \\
\hline Muhasebe Denetim & - & - & 2 & 0,54 \\
\hline Muhasebe ve Finansal Yönetim & - & - & 1 & 0,27 \\
\hline Spor & - & - & 1 & 0,27 \\
\hline Turizm & - & - & 1 & 0,27 \\
\hline Eğitim ve Öğretim & - & - & 1 & 0,27 \\
\hline Sağllk Kurumları İşletmeciliği & - & - & 1 & 0,27 \\
\hline Toplam & - & 100 & 371 & 100 \\
\hline
\end{tabular}

Yukarıdaki tablo 8'de muhasebe standartları ile finansal raporlama standartları konusundaki lisansüstü tezlerin anabilim dallarına göre dağılımı sunulmuştur. Tabloya göre ilgili konuda en fazla doktora tezi yazılan ilk üç anabilim dalı sırasıyla yüzde 88,66 'lık pay ile işletme, yüzde 3,09 ile maliye ve yüzde 2,06 ile kamu yönetimi ile maliye anabilim dallarıdır. İlgili konuda en fazla yüksek lisans tezi yazılan anabilim dalları sırasıly yüzde 86,25 ile işletme, yüzde 6,74 ile maliye ve yüzde 1,62 ile ekonomidir.

Tablo 9. Muhasebe Standartları ile Finansal Raporlama Standartları Kapsamındaki Lisansüstü Tezlerin Araştırma Yöntemlerine Göre Dağılımı

\begin{tabular}{|l|l|l|l|l|}
\hline Araştırma Yöntemleri & Doktora Tezi & Doktora Tezi \% & Yüksek Lisans Tezi & Yüksek Lisans Tezi \% \\
\hline BİST Uygulamas1 & 63 & 64,95 & 143 & 38,54 \\
\hline Anket & 11 & 11,34 & 30 & 8,09 \\
\hline Karş1laştırma & 10 & 10,31 & 72 & 19,41 \\
\hline Örnek uygulama & 5 & 5,15 & 28 & 7,55 \\
\hline Doküman inceleme & 3 & 3,09 & 91 & 24,53 \\
\hline İcerik analizi & 3 & 3,09 & 3 & 0,81 \\
\hline Finansal analiz & 2 & 2,06 & 4 & 1,08 \\
\hline Toplam & 97 & 100 & 371 & 100 \\
\hline
\end{tabular}

Yukarıda tablo 9'da muhasebe standartları ile finansal raporlama standartları konusundaki lisansüstü tezlerin araştırma yöntemlerine göre dağılımı sunulmuştur. Tablodaki 
verilere göre ilgili konuda yazılmış doktora tezlerinde en çok kullanılan araştırma yöntemi yüzde 64,95'lik pay ile BİST uygulamasıdır. Akabinde yüzde 11,34'lük pay ile anket yöntemi ve yüzde 10,31'lik pay ile karşılaştırma yöntemi kullanılmaktadır. Yüksek lisans tezlerinde en çok kullanılan araştırma yöntemleri ise sırasıyla yüzde 38,54'lük pay ile BİST uygulaması, yüzde 24,53'lük pay ile doküman inceleme ve yüzde 19,41'lik pay ile karşılaştırma yöntemidir. Dolayısıyla tablodaki verilerden hem doktora hem de yüksek lisans tezlerinde en çok kullanılan araştırma yönteminin BİST uygulamaları olduğu ve ilgili tezlerde, şirketlerin BİST' te yer alan gerçek finansal tablo verilerinden yararlanıldığını söylemek mümkündür.

Tablo 10. Muhasebe Standartları ile Finansal Raporlama Standartları Kapsamındaki Lisansüstü Tezlerin Konularına Göre Dağılımı

\begin{tabular}{|c|c|c|c|c|}
\hline Lisansüstü Tez Konusu & $\begin{array}{l}\text { Doktora } \\
\text { Tezi }\end{array}$ & $\begin{array}{l}\text { Doktora } \\
\text { Tezi \% }\end{array}$ & $\begin{array}{l}\text { Yüksek } \\
\text { Lisans } \\
\text { Tezi } \\
\end{array}$ & $\begin{array}{l}\text { Yüksek } \\
\text { Lisans } \\
\text { Tezi \% }\end{array}$ \\
\hline Avrupa'daki muhasebe standartlarının TMS ile karşılaştırılması & 5 & 5,15 & 12 & 3,23 \\
\hline $\begin{array}{l}\begin{array}{l}\text { TMS/TFRS ve VUK'da ve yer alan değerleme ölçütlerin } \\
\text { karşılaştırılmas1 }\end{array} \\
\end{array}$ & 5 & 5,15 & 8 & 2,16 \\
\hline $\begin{array}{l}\text { UMS/UFRS'lere göre türev finansal araçların muhasebeleştirilmesi ve } \\
\text { incelenmesi }\end{array}$ & 4 & 4,12 & 14 & 3,77 \\
\hline $\begin{array}{l}\text { İşletme birleşmeleri ve/veya devir işlemlerinin TMS-TFRS/ VUK veya } \\
\text { TTK açısından incelenmesi }\end{array}$ & 4 & 4,12 & 12 & 3,23 \\
\hline Maliyet ve giderlerin TMS/TFRS açısından incelenmesi & 3 & 3,09 & 8 & 2,16 \\
\hline UFRS'nın entegrasyon üzerindeki etkisi & 3 & 3,09 & 3 & 0,81 \\
\hline $\begin{array}{l}\text { Uluslararas1 muhasebe standartlarına göre varlıkların ve borçların } \\
\text { değerlemesi }\end{array}$ & 2 & 2,06 & 11 & 2,96 \\
\hline $\begin{array}{l}\text { TMS-TFRS ile VUK arasındaki değerleme farklarının ertelenmiş } \\
\text { vergilere etkisi }\end{array}$ & 2 & 2,06 & 9 & 2,43 \\
\hline UFRS 16 kiralama işlemleri & 2 & 2,06 & 9 & 2,43 \\
\hline TMS/TFRS'deki muhasebe uygulamalarının finansal tablolara etkisi & 2 & 2,06 & 8 & 2,16 \\
\hline UFRS'ye göre konsolide finansal tabloların düzenlenmesi & 2 & 2,06 & 8 & 2,16 \\
\hline KOBİ TFRS'nin incelenmesi & 2 & 2,06 & 7 & 1,89 \\
\hline UMS/UFRS'lere göre gelirin muhasebeleştirilmesi ve incelenmesi & 2 & 2,06 & 6 & 1,62 \\
\hline Dönem sonu işlemlerinin TMS-TFRS açısından incelenmesi & 2 & 2,06 & 6 & 1,62 \\
\hline $\begin{array}{l}\text { Muhasebe Sistemi Uygulama Genel Tebliğleri'nden TMS-TFRS'na } \\
\text { geçiş sürecinin incelenmesi }\end{array}$ & 2 & 2,06 & 5 & 1,35 \\
\hline TMS-TFRS'nin muhasebe uygulamalarına etkisi & 2 & 2,06 & 4 & 1,08 \\
\hline $\begin{array}{l}\text { TDHP ve TMS-TFRS açısından muhasebe uygulamalarının } \\
\text { karşılaştırılması }\end{array}$ & 2 & 2,06 & 2 & 0,54 \\
\hline TMS/TFRS açısından çevre muhasebesinin incelenmesi & 2 & 2,06 & 1 & 0,27 \\
\hline $\begin{array}{l}\text { UFRS ve VUK'a göre düzenlenen temel mali tabloların finansal analiz } \\
\text { açısından karşılaştırmalı olarak incelenmesi }\end{array}$ & 2 & 2,06 & 1 & 0,27 \\
\hline $\begin{array}{l}\text { UFRS açısından konsolidasyon yöntemleri ve bu yöntemlerin finansal } \\
\text { analize etkileri }\end{array}$ & 2 & 2,06 & 1 & 0,27 \\
\hline $\begin{array}{llll}\begin{array}{l}\text { Uluslararas1 finansal raporlama standartlarına göre etkin maliyet } \\
\text { denetimi }\end{array} & & & \\
\end{array}$ & 2 & 2,06 & 1 & 0,27 \\
\hline Çalışanlara sağlanan faydaların TFRS çerçevesinde incelenmesi & 2 & 2,06 & - & - \\
\hline Finansal raporlama standartlarının muhasebe kalitesi üzerine etkisi & 2 & 2,06 & - & - \\
\hline TMS-TFRS kapsamında tarımsal faaliyetlerin muhasebeleştirilmesi & 2 & 2,06 & - & - \\
\hline UMS 2 stoklar standardının incelenmesi & 1 & 1,03 & 15 & 4,04 \\
\hline $\begin{array}{lccccc}\begin{array}{l}\text { Amortisman } \\
\text { incelenmesi }\end{array} & \text { uygulamalarının } & \text { TMS-TFRS } & \text { ve } & \text { VUK } & \text { açısından } \\
\end{array}$ & 1 & 1,03 & 11 & 2,96 \\
\hline $\begin{array}{llllll}\begin{array}{l}\text { Finansal analiz } \\
\text { karşılaştırılması }\end{array} & \text { sonuçlarının } & \text { VUK } & \text { ve } & \text { TMS/TFRS } & \text { açısından } \\
\end{array}$ & 1 & 1,03 & 5 & 1,35 \\
\hline $\begin{array}{l}\text { Türk Vergi Kanunları ve Uluslararası Muhasebe Standartları (UMS) } \\
\text { arasında karşılaştırma }\end{array}$ & 1 & 1,03 & 4 & 1,08 \\
\hline Muhasebe meslek mensuplarının TMS-TFRS algılarının incelenmesi & 1 & 1,03 & 4 & 1,08 \\
\hline $\begin{array}{l}\text { Sigorta işletmelerinde muhasebe uygulamalarının TMS-TFRS açısından } \\
\text { incelenmesi }\end{array}$ & 1 & 1,03 & 3 & 0,81 \\
\hline MSUGT, BOBİ FRS ve TMS/TFRS açısından ölçme/değerleme ve & 1 & 1,03 & 3 & 0,81 \\
\hline
\end{tabular}




\begin{tabular}{|c|c|c|c|c|}
\hline raporlama esaslarının incelenmesi & & & & \\
\hline TMS-TFRS ve VUK hükümleri uyarınca kârın tespiti & 1 & 1,03 & 3 & 0,81 \\
\hline UMS'nın işletme karı üzerine etkisi & 1 & 1,03 & 2 & 0,54 \\
\hline $\begin{array}{l}\text { Eğitimde sunulan muhasebe eğitiminin TMS/TFRS ile uyumunun } \\
\text { incelenmesi }\end{array}$ & 1 & 1,03 & 2 & 0,54 \\
\hline Kamu sektöründe muhasebe standartları ve tahakkuk esası & 1 & 1,03 & 2 & 0,54 \\
\hline 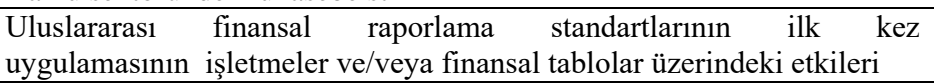 & 1 & 1,03 & 2 & 0,54 \\
\hline $\begin{array}{l}\text { Faizsiz bankacılık fon kullandırma yöntemlerinin UMS kapsamında } \\
\text { incelenmesi }\end{array}$ & 1 & 1,03 & 2 & 0,54 \\
\hline $\begin{array}{l}\text { UMS/UFRS'nin Azerbaycan'da } \text { uygulama etkinliğine ilişkin bir } \\
\text { araştırma }\end{array}$ & 1 & 1,03 & 1 & 0,27 \\
\hline $\begin{array}{l}\text { Banka finansal tablolarında sunulan muhasebe politikalarının TMS- } \\
\text { TFRS açısından incelenmesi }\end{array}$ & 1 & 1,03 & 1 & 0,27 \\
\hline UMS/UFRS’nin bilgi asimetrisine etkisi & 1 & 1,03 & - & - \\
\hline Muhasebe bilgi sistemlerini kullanmanın UMS açısından incelenmesi & 1 & 1,03 & - & - \\
\hline $\begin{array}{l}\text { İşletme birleşmeleri ve/veya devir işlemlerinin UFRS, VUK Amerika'da } \\
\text { genel kabul görmüş muhasebe standartları açısından incelenmesi }\end{array}$ & 1 & 1,03 & - & - \\
\hline UFRS çerçevesinde aracı kurumlar için finansal raporlama önerisi & 1 & 1,03 & - & - \\
\hline $\begin{array}{l}\text { Dipnotlarda sunulan muhasebe politikalarının UFRS açısından } \\
\text { incelenmesi }\end{array}$ & 1 & 1,03 & - & - \\
\hline $\begin{array}{l}\text { UFRS'ye geçişin tahakkukların güvenilirliği ve kazançların süreğenliği } \\
\text { üzerine etkisi }\end{array}$ & 1 & 1,03 & - & - \\
\hline TFRS’nin Türk muhasebe hukuku açısından incelenmesi & 1 & 1,03 & - & - \\
\hline $\begin{array}{l}\text { Uluslararas1 finansal raporlama standartlarının şirketler üzerindeki } \\
\text { etkileri }\end{array}$ & 1 & 1,03 & - & - \\
\hline İnsan kaynakları muhasebesi çerçevesinde TMS'nin incelenmesi & 1 & 1,03 & - & - \\
\hline $\begin{array}{l}\text { Uluslararası finansal raporlama standartlarının şirketler üzerindeki } \\
\text { etkileri }\end{array}$ & 1 & 1,03 & - & - \\
\hline $\begin{array}{l}\text { UFRS'de yapılan düzenlemelerin finansal tablo kullanıcıları üzerindeki } \\
\text { etkilerinin incelenmesi }\end{array}$ & 1 & 1,03 & - & - \\
\hline Vadeli işlemlere yönelik UFRS'nin değerlendirilmesi & 1 & 1,03 & - & - \\
\hline $\begin{array}{lcccc}\text { UFRS ve KOBİ } & \text { TFRS } & \text { çerçevesinde } & \text { ortaklık yatırımlarının } \\
\text { muhasebeleştirilmesi }\end{array}$ & 1 & 1,03 & - & - \\
\hline TMS çerçevesinde insan kaynakları muhasebesinin incelenmesi & 1 & 1,03 & - & - \\
\hline Yazılım maliyetlerinin TMS'ye göre muhasebeleştirilmesi & 1 & 1,03 & - & - \\
\hline $\begin{array}{l}\text { Entelektüel sermayenin TMS çerçevesinde finansal durum tablosunda } \\
\text { raporlanması }\end{array}$ & 1 & 1,03 & - & - \\
\hline $\begin{array}{l}\text { Raporlama döneminden } \\
\text { incelenmesi }\end{array}$ & 1 & 1,03 & - & - \\
\hline $\begin{array}{l}\text { UMS-UFRS'nin gelişmekte olan ülkelerde uygulanabilirliği ve kabul } \\
\text { görmüşlüğü }\end{array}$ & 1 & 1,03 & - & - \\
\hline Yenilenebilir enerji üreten işletmelerin TMS açısından değerlendirilmesi & 1 & 1,03 & - & - \\
\hline perakende mağazacılık sektöründe UMS'ye göre bütçeleme & 1 & 1,03 & - & - \\
\hline $\begin{array}{l}\text { İşletmelerde performans raporlamasının muhasebe standartları açısından } \\
\text { analizi }\end{array}$ & 1 & 1,03 & - & - \\
\hline $\begin{array}{l}\text { Duran varlıklarda değer azalışları ve Amerika finansal muhasebe } \\
\text { standartları 144'ün incelenmesi }\end{array}$ & 1 & 1,03 & - & - \\
\hline Maddi duran varlıkların TMS-TFRS açısından değerlendirilmesi & - & - & 10 & 2,70 \\
\hline Muhasebe standartlarında hasilat & - & - & 9 & 2,43 \\
\hline $\begin{array}{lllll}\text { İnşaat işlemlerinin } & \text { muhasebeleştirilmesinde } & \text { VUK } & \text { ve } & \text { TMS } \\
\text { karş1laştırması }\end{array}$ & - & - & 9 & 2,43 \\
\hline Diş ticaret işlemlerinin UMS-UFRS'ye göre muhasebeleştirilmesi & - & - & 8 & 2,16 \\
\hline $\begin{array}{l}\text { Yıllara yaygın inşaat, taahhüt ve onarım işlemlerinin TFRS } 15 \\
\text { kapsamında incelenmesi }\end{array}$ & - & - & 8 & 2,16 \\
\hline $\begin{array}{llll}\begin{array}{l}\text { Araştırma ve geliştirme } \\
\text { muhasebeleştirilmesi }\end{array} & \text { faaliyetlerinin } & \text { TFRS } & \text { kapsamında } \\
\end{array}$ & - & - & 8 & 2,16 \\
\hline $\begin{array}{l}\text { Muhasebe Sistemi Uygulama Genel Tebliği } \\
\text { düzenlenen finansal tablo setinin TMS/TFRS } \\
\text { dönüşstürülmesi }\end{array}$ & - & - & 8 & 2,16 \\
\hline Devlet teşvik ve yardımlarının muhasebeleştirilmesinin TMS/TFRS- & - & - & 8 & 2,16 \\
\hline
\end{tabular}




\begin{tabular}{|c|c|c|c|c|}
\hline BOBİ FRS ile vergi sistemi kapsamında incelenmesi & & & & \\
\hline TMS-TFRS'ye göre finansal tabloların sunumu & - & - & 7 & 1,89 \\
\hline Finansal araçların muhasebeleştirilmesi ve/veya ölçümü & - & - & 7 & 1,89 \\
\hline Maddi duran varlıkların VUK ile TMS/TFRS açısından incelenmesi & - & - & 6 & 1,62 \\
\hline BOBİ FRS ile TMS/TFRS karşılaştırması & - & - & 5 & 1,35 \\
\hline $\begin{array}{l}\text { Özel tükenmeye tabi varlıkların TMS/TFRS ve VUK açısından } \\
\text { incelenmesi ve değerlemesi }\end{array}$ & - & - & 4 & 1,08 \\
\hline Muhasebe meslek mensuplarının KOBİ TFRS algılarının incelenmesi & - & - & 4 & 1,08 \\
\hline Varlıklarda değer düşüklüğün TMS'na göre raporlanması & - & - & 3 & 0,81 \\
\hline $\begin{array}{l}\text { UFRS açısından ara dönem mali tablolarda uyulması gereken esasların } \\
\text { incelenmesi }\end{array}$ & - & - & 3 & 0,81 \\
\hline TMS-TFRS'nin ortaya çıkışı ve gelişim sürecine ilişkin içerik analizi & - & - & 3 & 0,81 \\
\hline Faizsiz finansal muhasebe standartlarının TFRS'na uyumu & - & - & 3 & 0,81 \\
\hline Türkiye'de UMS-UFRS'nin gerekliliği ve uygulanabilirliği & - & - & 2 & 0,54 \\
\hline $\begin{array}{l}\text { Uluslararası finansal raporlama standartlarının kamu kurumlarında } \\
\text { kullanılmasının mali saydamlığa etkisi }\end{array}$ & - & - & 2 & 0,54 \\
\hline UFRS'nin Kırgızistan'da uygulama etkinliğine ilişkin bir araştırma & - & - & 2 & 0,54 \\
\hline TFRS'ye göre hazırlanmış nakit akış tablosunun analizi & - & - & 2 & 0,54 \\
\hline $\begin{array}{llllll}\begin{array}{l}\text { Bağımsız denetim } \\
\text { karşılaştırılması }\end{array} & \text { açısından } & \text { TFRS'nin } & \text { ve } & \text { BOBİ } & \text { FRS'nin } \\
\end{array}$ & - & - & 2 & 0,54 \\
\hline $\begin{array}{l}\text { TFRS'nin temel mali tabloların düzenlenmesi açısından getirdikleri ve } \\
\text { tekdüzen hesap planı ile karşılaştırması }\end{array}$ & - & - & 2 & 0,54 \\
\hline UFRS'nın firma değerlemesi üzerine etkisi & - & - & 2 & 0,54 \\
\hline TMS çerçevesinde canlı varlıkların değerlemesi ve muhasebeleştirilmesi & - & - & 2 & 0,54 \\
\hline $\begin{array}{l}\text { Borçlanma maliyetlerinin UMS, VUK ve sermaye piyasası mevzuatı } \\
\text { kapsamında incelenmesi }\end{array}$ & - & - & 2 & 0,54 \\
\hline $\begin{array}{l}\text { Rus muhasebe standartları (RMS) ile uluslararası finansal raporlama } \\
\text { standartlarının (UFRS) karşılaştırmas1 }\end{array}$ & - & - & 1 & 0,27 \\
\hline UMS-18 gelir tahakkuku & - & - & 1 & 0,27 \\
\hline UMS 14 kapsamında bölümlere göre raporlama esasları & - & - & 1 & 0,27 \\
\hline $\begin{array}{l}\text { UMS } 12 \text { gelir vergileri standardı kapsamında ertelenmiş vergiler ve ırak } \\
\text { vergi mevzuatı ile karşılaştırılması }\end{array}$ & - & - & 1 & 0,27 \\
\hline $\begin{array}{l}\text { Gerçeğe uygun değerin amerikan genel kabul görmüş muhasebe } \\
\text { prensiplerine ve uluslararası finansal raporlama standartları açısından } \\
\text { incelenmesi }\end{array}$ & - & - & 1 & 0,27 \\
\hline $\begin{array}{l}\text { Maddi olmayan duran varlıklar ve şerefiyenin UMS-UFRS ve amerikan } \\
\text { genel kabul görmüş muhasebe prensiplerine göre muhasebelestirilmesi } \\
\text { ve değerlemesi }\end{array}$ & - & - & 1 & 0,27 \\
\hline $\begin{array}{l}\text { Maddi olmayan duran varlıkların TMS, THDP ve VUK yönünden } \\
\text { incelenmesi }\end{array}$ & - & - & 1 & 0,27 \\
\hline Vakıflarda UFRS'nin uygulanması & - & - & 1 & 0,27 \\
\hline $\begin{array}{l}\text { Taşıyıcı bitkilerin TMS-TFRS çerçevesinde muhasebeleştirilmesi ve } \\
\text { raporlanması }\end{array}$ & - & - & 1 & 0,27 \\
\hline $\begin{array}{l}\text { Bankaların enflasyon muhasebesi uygulaması ve UFRS } 29 \text { açısından } \\
\text { incelenmesi }\end{array}$ & - & - & 1 & 0,27 \\
\hline $\begin{array}{l}\text { Uluslararas1 muhasebe standartları ve Rusya Federasyonun'daki } \\
\text { uygulamaların incelenmesi }\end{array}$ & - & - & 1 & 0,27 \\
\hline $\begin{array}{l}\text { Ortaöğretim düzeyindeki muhasebe ve finansman öğrencilerinin } \\
\text { TMS/TFRS farkındalık düzeylerinin ölçülmesi }\end{array}$ & - & - & 1 & 0,27 \\
\hline TFRS'nin kurumsal yönetim anlayışı kapsamında incelenmesi & - & - & 1 & 0,27 \\
\hline $\begin{array}{l}\begin{array}{l}\text { Lisans öğrencilerinin TMS-TFRS hakkındaki ilgi düzeylerinin } \\
\text { incelenmesi }\end{array} \\
\end{array}$ & - & - & 1 & 0,27 \\
\hline TMS-TFRS ile VUK düzenlemelerinin incelenmesi & - & - & 1 & 0,27 \\
\hline $\begin{array}{l}\text { Sermaye piyasası kurulu kurumsal yönetim ilkeleri ile TMS-TFRS'nin } \\
\text { etkileşimi }\end{array}$ & - & - & 1 & 0,27 \\
\hline Faaliyet bölümlerine ilişkin raporlamanın TFRS açısından incelenmesi & - & - & 1 & 0,27 \\
\hline $\begin{array}{l}\text { UMS-UFRS’nın şirketlerin finansal performansı üzerine etkisinin } \\
\text { incelenmesi }\end{array}$ & - & - & 1 & 0,27 \\
\hline $\begin{array}{l}\text { UFRS'nin türk sermaye piyasasının şeffaflık seviyesine etkisinin } \\
\text { incelenmesi }\end{array}$ & - & - & 1 & 0,27 \\
\hline Cari olmayan varlıklarla ilgili TFRS'nin tekdüzen hesap planı ile & - & - & 1 & 0,27 \\
\hline
\end{tabular}




\begin{tabular}{|c|c|c|c|c|}
\hline uyumluluğu & & & & \\
\hline TMS-TFRS uygulamalarında yaşanan sorunlar & - & - & 1 & 0,27 \\
\hline $\begin{array}{l}\text { Maden işletmelerinde rehabilitasyon giderlerinin TMS-TFRS açısından } \\
\text { incelenmesi }\end{array}$ & - & - & 1 & 0,27 \\
\hline $\begin{array}{l}\text { Maden işletmelerinde duran varlıklar için ayrılmış amortismanların } \\
\text { UMS ve VUK açısından değerlendirilmesi }\end{array}$ & - & - & 1 & 0,27 \\
\hline Yabancı para birimi çevrimlerinde bir türk muhasebe standardı önerisi & - & - & 1 & 0,27 \\
\hline $\begin{array}{l}\text { Karşılıkların TMS-TFRS'ye göre muhasebeleştirilmesi ve Vergi Usul } \\
\text { Kanunu ile karşslaştırılması }\end{array}$ & - & - & 1 & 0,27 \\
\hline Hisse bazlı ödemelerin TMS ve VUK açısından incelenmesi & - & - & & - \\
\hline Murabaha işlemlerinin TMS-TFRS kapsamında değerlendirilmesi & - & - & 1 & 0,27 \\
\hline $\begin{array}{l}\begin{array}{l}\text { Teknoloji transfer faaliyetlerinin } \\
\text { incelenmesi }\end{array} \\
\end{array}$ & - & - & 1 & 0,27 \\
\hline Türkiye muhasebe standartlarının liman işletmeciliğine uygulanması & - & - & 1 & 0,27 \\
\hline Sağlik işletmelerinde TMS’ye uyum & - & - & 1 & 0,27 \\
\hline Yönetim muhasebesinin UMS'na uygun olarak yeniden yapılanması & - & - & 1 & 0,27 \\
\hline Leasing işlemlerinin TMS-TFRS'ye göre muhasebeleştirilmesi & - & - & 1 & 0,27 \\
\hline $\begin{array}{l}\text { Tek düzen hesap planında vadeli işlemlerin muhasebeleştirilmesinde } \\
\text { ortaya çıkan sorunların UMS açısından incelenmesi }\end{array}$ & - & - & 1 & 0,27 \\
\hline TMS ve VUK arasındaki uyumun bilançoya yansımaları & - & - & 1 & 0,27 \\
\hline Gayrimenkullerin TMS-TFRS açısından incelenmesi & - & - & 1 & 0,27 \\
\hline TMS-TFRS'nin uygulanmasında mesleki yarg1 gerektiren durumlar & - & - & 1 & 0,27 \\
\hline TMS’nin faktoring işlemlerinin muhasebesine etkileri & - & - & 1 & 0,27 \\
\hline $\begin{array}{l}\text { Siyasi partilere önerilen muhasebe sistemi ve önerilen hesap planının } \\
\text { TMS ile uyumlaştırılması }\end{array}$ & - & - & 1 & 0,27 \\
\hline TMS'ye göre sermaye piyasasına tabi kurumların vergilendirilmesi & - & - & 1 & 0,27 \\
\hline UMS açısından katma değer hesaplamasının incelenmesi & - & - & 1 & 0,27 \\
\hline Uluslararası muhasebe standartlarının uyumlaştırılmasında kültür etkisi & - & - & 1 & 0,27 \\
\hline UMS'nin maliyet muhasebesi uygulamas1 & - & - & 1 & 0,27 \\
\hline $\begin{array}{l}\text { TMS açısından zirai işletmelerin muhasebeleştirilmesi muhasebe } \\
\text { uygulaması }\end{array}$ & - & - & 1 & 0,27 \\
\hline $\begin{array}{l}\text { Avrupa Birliği ve Türkiye'de çevre korumaya yönelik teşvik ve } \\
\text { yardımların TMS'ye göre muhasebeleştirilmesi }\end{array}$ & - & - & 1 & 0,27 \\
\hline TMS-TFRS uygulamalarının bağımsız denetim sürecine etkisi & - & - & 1 & 0,27 \\
\hline Toplam & 97 & 100 & 371 & 100 \\
\hline
\end{tabular}

Yukarıda tablo 10'da muhasebe standartları ile finansal raporlama standartları kapsamındaki lisansüstü tezlerin konularına göre dağılımı sunulmuş. Tabloya göre doktora tezlerinin en yoğun olarak TMS/TFRS ve VUK'da ve yer alan değerleme ölçütlerinin karşılaştırılması ile Avrupa'daki muhasebe standartlarının Türkiye muhasebe standartları ile karşılaştııılması konularında yazılmıştır. Yüksek lisans tezleri açısından değerlendirildiğinde ise UMS 2 stoklar standardı ile UMS/UFRS'lere göre türev finansal araçların muhasebeleştirilmesi ve incelenmesi bu aşamada üzerinde en yoğun tez yazılan konulardır. Dolayısıyla bu veriler ışında ülkemizde muhasebe standartları ile finansal raporlama standartları kapsamında en fazla doktora tezinin hazırlandığı, TMS/TFRS ile Vergi Usul Kanunu kapsamındaki değerleme ölçütlerinin karşılaştııılmasının ve Ülkemiz muhasebe standartlarının Avrupa'daki muhasebe standartları ile karşılaştırılmasının, halen cevaplanması gereken önemli soruları içerdiğini ve bu nedenle doktora tezi kapsamında daha ayrıntılı olarak incelendiğini söylemek mümkündür. 
Tablo 11. Muhasebe Standartları ile Finansal Raporlama Standartları Kapsamında Lisansüstü Tez Çalışması Bulunmayan Standartlar

\begin{tabular}{|l|l|}
\hline \multicolumn{2}{|l|}{ Lisansüstü Tez Çalışması Bulunmayan Standartlar } \\
\hline TFRS 6 & Maden Kaynaklarının Araştırılması ve Değerlendirilmesi \\
\hline TFRS 14 & Düzenlemeye Dayalı Erteleme Hesapları \\
\hline TMS 26 & Emeklilik Fayda Planlarında Muhasebeleştirme ve Raporlama \\
\hline
\end{tabular}

Yukarıda Tablo 11'de muhasebe standartları ile finansal raporlama standartları kapsamında, lisansüstü bir tez çalışmasına konu olmadığı saptanmış olan bir adet muhasebe standardı ve iki adet finansal raporlama standardı sunulmuştur.

\section{SONUÇ VE ÖNERİLER}

Bu çalışmada Muhasebe Standartları-Finansal Raporlama Standartları kapsamında yazılmış ve YÖK Ulusal Tez Merkezi'nde bilgileri sunulmuş bulunan 468 lisansüstü tez, belirli ölçütler doğrultusunda bibliyometrik analiz yöntemi ile incelenmiştir. Çalışma Muhasebe Standartları-Finansal Raporlama Standartları kapsamında hazırlanmış olan lisansüstü tezler ile kısıtlanmıştır. Bu tezlere ilişkin yapılan analiz neticesinde elde edilen sonuçlar, ülkemizde Muhasebe Standartları-Finansal Raporlama Standartları kapsamında ilk lisansüstü tezin 1992 yılında bir doktora tezi türünde yazıldığını ortaya koymaktadır. Bununla birlikte ülkemizde Muhasebe Standartları-Finansal Raporlama Standartları kapsamında yazılmış toplam lisansüstü tez sayısı 2005 yılı itibariyle artmaya başlamış ve 2019 yılında toplam 58 lisansüstü tez sayısı ile en yüksek seviyesine ulaşmıştır. İlgili konu kapsamında hazırlanan lisansüstü tezlerden yüzde 21,74'ünün doktora tezi ve yüzde 20,92'sinin ise yüksek lisans tezi kapsamında en fazla Marmara Üniversitesi bünyesinde hazırlandığı da araştırmadan elde edilen sonuçlar arasındadır. Lisansüstü tezler kısıtlılık durumu açısından değerlendirildiğinde, doktora tezlerinin yüzde 11,34'ünde ve yüksek lisans tezlerinin yüzde 9,16'sında erişim kısıtı bulunmaktadır. Lisansüstü tezler özgün dilleri bakımından incelendiğinde, Türkçe özgün dili haricinde, doktora tezlerinin yüzde 7, 22'si İngilizce ve yüzde 2,06's1 Almanca ve yüksek lisans tezlerinin ise yüzde 3,5'i İngilizce ve yüzde 1,08'i Almaca özgün dilinde yazılmıştır. Bununla birlikte doktora tezlerinin yüzde 69,07'si Prof. Dr. ve yüksek lisans tezlerinin yüzde 42,59’u Doç. Dr. unvanına sahip akademisyenler danışmanlığında hazırlanmıştır. Muhasebe Standartları-Finansal Raporlama Standartları kapsamında yazılmış lisansüstü tezler sırasıyla en fazla işletme, maliye, kamu yönetimi ve ekonomi anabilim dallarında yazılmıştır. Ayrıca ilgili konuda yazılmış lisansüstü tezlerde en fazla kullanılan araştırma yöntemi BİST uygulamasıdır. Araştırma kapsamında yapılan bibliyometrik analiz neticesinde Muhasebe Standartlar1-Finansal Raporlama Standartları kapsamında doktora tezlerinin yoğun olarak TMS/TFRS ve VUK'da ve yer alan değerleme esaslarının karşılaştırılması ile Avrupa'daki muhasebe standartlarının Türkiye muhasebe standartları ile karşılaştırılması konularında; yüksek lisans tezlerinin ise yoğun olarak UMS 2 stoklar standardı ile standartlara göre türev finansal araçların muhasebeleştirilmesi ve incelenmesi konularında yazıldığı ortaya konulmuştur. Yapılan bibliyometrik analiz neticesinde ayrıca bir lisansüstü tez çalışmasına konu olmayan standartlar da belirlenmiştir. Bunlar "TFRS 6 Maden Kaynaklarının Araştırılması ve Değerlendirilmesi", "TFRS 14 Düzenlemeye Dayalı Erteleme Hesapları", "TMS 26 Emeklilik Fayda Planlarında Muhasebeleştirme ve Raporlama” Standartlarıdır. 
Muhasebe Standartları-Finansal Raporlama Standartları kapsamında yazılmış lisansüstü tezlerin bibliyometrik analizine ilişkin yapılmış ve lisansüstü tezler ile kısıtlanmış olan bu çalışma ile ülkemizde muhasebe standartları ve finansal raporlama standartlarının gelişimi, gelecekteki eğiliminin ortaya konulması ve ilgili konuda lisansüstü tez hazırlamak isteyen öğrencilere fikir sağlanması hedeflenmiştir. Ayrıca bir lisansüstü tez çalışmasına konu olmadığı saptanan standartlara yönelik çalışmaların teşvik edilmesi amaçlanmıştır. Bu doğrultuda sonraki süreçte yapılacak çalışmalarda muhasebe standartları ve finansal raporlama standartları konusunda, yurt dışındaki üniversitelerde hazırlanmış lisansüstü tezlere ilişkin bilgilerin, ülkemizdeki veriler ile karşılaştırılmalı olarak incelenmesi hedeflenmektedir.

\section{KAYNAKLAR}

Akdoğan, Nalan (2006), "Türkiye Muhasebe Standartlarının İlk Uygulanmasında Uygulanacak Esaslar ve TFRS'ye Geçiş Bilançosunun Düzenlenmesi", Muhasebe Bilim Dünyası Dergisi, 8(1), ss. 2-3

Al, Umut (2008), Türkiye'nin Bilimsel Yayın Politikası: Atıf Dizinlerine Dayalı Bibliyometrik Bir Yaklaşım, Doktora Tezi, Hacettepe Üniversitesi, Sosyal Bilimler Enstitüsü.

Alkan, Gönül (2014), "Türkiye'de Muhasebe Alanında Yapılan Lisansüstü Tez Çalışmaları Üzerine Bir Araştırma (1984-2012)", Muhasebe ve Finansman Dergisi, 61, ss. 41-52

Balstad, Marit Terese - Berg, Terje (2020), " A Long-Term Bibliometric Analysis of Journals İnfluencing Management Accounting and Control Research", Journal of Management Control, 30(4), pp. 357-380

Cardoso, Ricardo Lopes - Oyadomari, José Carlos T. - Neto, Octavio Ribeiro de Mendonça (2007), "The Influence of Positive Accounting in Postgraduate Programs in Accounting: A Bibliometric Analysis of Brazilian Academic Production From 2002 Through 2005", Brazilian Business Review (BBR), 4(2), pp. 149-161

Çarıkçı, Oğuzhan - Yaman, Bahar (2019), "Muhasebe-Finans Öğrencileri Üzerine Yapılan Araştırmaların Bibliyometrik Analizi", Kafkas Üniversitesi İktisadi ve İdari Bilimler Fakültesi Dergisi, 10(19), ss. 359-381

Durgut, Sinan (2020), "Türkiye'de Yapılan Akademik Çalışmaların Büyük Veri Araçları ile Bibliyometrik Analizi", Süleyman Demirel Üniversitesi Fen Bilimleri Enstitüsü, Yüksek Lisans Tezi.

Dworczak, Beata Zyznarska - Sačer, Ivana Mamić (2019), "Accounting Systems in Poland and Croatia - Comparative Study", Zagreb International Review of Economics and Business, 22(1), pp. 55-72

Ezenwoke, Omotola - Tion, Williams (2020), "International Financial Reporting Standards (IFRSs) Adoption in Africa: Abibliometric Analysis", Cogent Social Sciences, 6(1), pp. 1-20 
Fallatah, Emad - Saat, Nur Ashikin Mohd - Shah, Sabarina Mohammed - Chong, Choo Wei (2021), "A Bibliometric Study of IFRS Adoption and Audit Quality", Academy of Accounting and Financial Studies Journal, 25(4), pp. 1-14

Fülbier, Rolf Uwe - Weller, Manuel (2011), " A Glance at German Financial Accounting Research Between 1950 and 2005: A Publication and Citation Analysis", Schmalenbach Business Review, 63(1), pp. 2-33

Gündüz, Meral (2018), "Türkiye'de 2014-2016 Yılları Arasında Akademik Dergilerde Muhasebe Alanında Yayınlanan Makalelerïn Bibliyometrik Analizi", Muhasebe Bilim Dünyası Dergisi, 20(1), ss. 236-257

Koç, Feden (2018), TMS/TFRS ile Vergi Mevzuatındaki Değerleme Farklılıklarının Finansal Durum Tablosu Üzerine Etkisi: BİST'deki İşletmelerin Uygulamaları Üzerine Bir Analiz, Doktora Tezi, Süleyman Demirel Üniversitesi Sosyal Bilimler Enstitüsü.

Lawani, Stephen M. (1981), "Bibliyometrics: Its Theoretical Foundations, Methods and Applications", International Journal of Libraries and Information Services, 31(4), pp. 294-295

Merigó, José M. - Yang, Jian-Bo (2017), "Accounting Research: A Bibliometric Analysis: Accounting Research: A Bibliometric Analysis", Australian Accounting Review, 27(1), pp. 71

Özbek, Cevdet Yiğit- Badem, Ahmet Cemkut (2018), "Muhasebe ve Vergi Uygulamaları Dergisi'nde Yayımlanmış Makalelerin Bibliyometrik Analizi (2008-2017)", Muhasebe ve Vergi Uygulamaları Dergisi, 11(2), ss. 32

Yeşil, Tolga - Akyüz, Fatma (2018), "Muhasebe Alanındaki Ulusal Doktora Tezlerinin Bibliyometrik Analizi", Muhasebe Bilim Dünyası Dergisi, 20 (özel sayı), ss. 440-472

Zan, Burcu Umut (2012), "Türkiye'de Bilim Dallarında Karşılaştırmalı Bibliyometrik Analiz Çalışması", Yüksek Lisans Tezi, Ankara Üniversitesi, Sosyal Bilimler Enstitüsü, ss. 1264

Zhong, Shaozhuo - Geng, Yong - Liu, Wenjing - Gao, Cuixia - Chen, Wei (2016), “A Bibliometric Review On Natural Resource Accounting During 1995-2014”, Journal of Cleaner Production, (139), pp. 122-132 
